
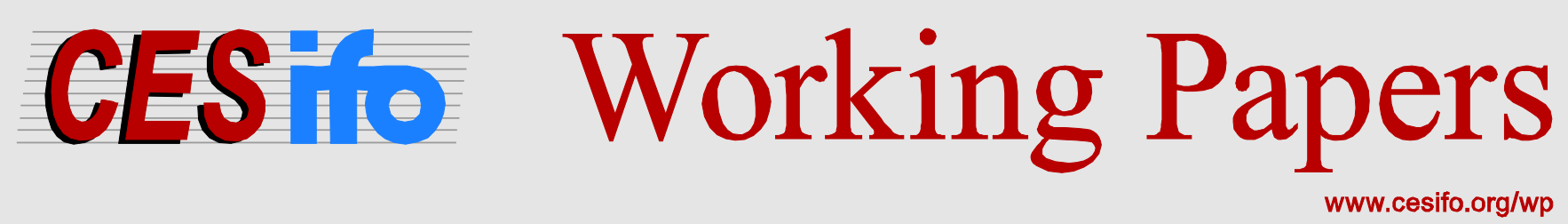

\title{
Public Child Care and Mothers' Labor Supply - Evidence from Two Quasi-Experiments
}

\author{
Stefan Bauernschuster \\ Martin Schlotter
}

CESIFO WORKING PAPER NO. 4191

CATEGORY 4: LABOUR MARKETS

APRIL 2013

An electronic version of the paper may be downloaded

- from the SSRN website:

- from the RePEc website:

- from the CESifo website:

WWW.SSRN.com

www.RePEc.org

www.CESifo-group.org/wp

\section{CESifo}




\title{
Public Child Care and Mothers’ Labor Supply - Evidence from Two Quasi-Experiments
}

\begin{abstract}
Public child care is expected to assist families in reconciling work with family life. Yet, empirical evidence for the relevance of public child care to maternal employment is inconclusive. We exploit the introduction of a legal claim to a place in kindergarten in Germany, which was contingent on day-of-birth cut-off dates and resulted in a marked increase in kindergarten attendance of three-year olds in the following years. Instrumental variable and difference-indifferences estimations on two individual-level data sets yield large and positive effects of public child care on maternal employment. A set of placebo treatment tests corroborate the validity of our identification strategies.
\end{abstract}

JEL-Code: J220, J130, D040.

Keywords: public child care, maternal employment.

\author{
Stefan Bauernschuster \\ University of Passau \\ Innstr. 27 \\ 94032 Passau, Germany \\ stefan.bauernschuster@uni-passau.de
}

\author{
Martin Schlotter \\ Bavarian Ministry of Economic Affairs, \\ Infrastructure, Transport and \\ Technology \\ Prinzregentenstr. 28 \\ 81679 Munich, Germany \\ Phone: $+49(0) 89 / 2160-2275$
}

We are indebted to Martha Bailey, Rainald Borck, Oliver Falck, Martin Halla, Timo Hener, Christian Holzner, Helmut Rainer, Ludger Woessmann, Josef Zweimueller, participants of the CESifo Area Conference on Employment and Social Protection in Munich, the SOLE Annual Meeting in Chicago, the meeting of the German Economic Association in Goettingen, the EALE conference in Bonn, the RES conference in London as well as seminar participants at the University of Munich, the University of Oslo, the University of Stockholm, and the ifo Institute for valuable comments and suggestions. 


\section{Introduction}

Recent years have witnessed substantial political effort to increase public child care provision in many industrialized countries. Providing subsidized child care is supposed to promote reconciliation of work and family life for the mothers of young children and increase their labor force participation. However, empirical studies find mixed results for the actual effects of subsidized public child care on mothers' employment. For some countries, economists have identified clearly positive effects. For other countries, reforms which aimed at increasing availability or affordability of public child care had zero effects on maternal employment (or effects that are substantially smaller than the take-up rate). In particular, marginal decreases in the costs of child care do not affect maternal labor supply if employment rates and child care attendance rates are already high. Further, we should not expect substantial employment effects if newly available public child care slots simply crowd-out existing private child care arrangements. Crowding-out might be particularly relevant if public child care slots are still severely rationed after expansion. It might be that the newly provided public child slots are then primarily given to mothers already closely attached to the labor market, and that these mothers now just substitute private care with public care arrangements.

This paper contributes to the growing empirical literature on child care and maternal employment by providing first quasi-experimental evidence from a German public child care reform introduced in 1996. At that time, West Germany had long been known for its low female and, in particular, maternal labor force participation. Indeed, the employment gap between mothers of three to four year old children and women of a similar age but without any children amounted to 40 percentage points in 1995. To improve reconciliation of family and working life, expansion of public child care has been at the top of the political agenda for the past two decades. One of the most prominent political reforms in this context was the introduction of the legal claim to a place in kindergarten (Rechtsanspruch auf einen Kindergartenplatz) in August 1996. Since that year, children from age three until school entry are eligible to attend highly subsidized half-day public child care. Thus, this reform intended to abandon any rationing of public child care for three to six year olds. While public child care attendance by five- and six-year old children was already at a very high level of 90 percent prior to the reform in West Germany, attendance by three- and four-year old children was substantially lower at 30 percent and 60 percent respectively. Despite the fact that public provision of child care has thus been far from universal (and non-existing for children under three), virtually no private market for child care had emerged. As expected the introduction of the legal claim to a place in kindergarten triggered a sharp increase in public child care attendance by three- and four-year olds from 1996 to 2001. It is surprising that, to the best 
of our knowledge, the effects of the 1996 policy reform have not yet been analysed. Indeed, the scarce German evidence that does exist on the relationship between public child care and mothers' labor supply is largely descriptive. ${ }^{1}$ However, this reform might give us interesting insights which are relevant for systemizing recent findings in the literature on public child care and maternal employment. In particular, our reading of the current literature suggests that we should expect large and positive effects of public child care on maternal labor supply in West Germany since a) the reform abandoned any rationing of public child care, b) there was no private market for child care which could be crowded out by a public child care expansion, and c) maternal employment rates were low at the time the reform set in.

The special features of the German policy reform in 1996 allow us to compare instrumental variables and difference-in-differences estimates within a single paper. In our first identification strategy, we exploit the fact that after introduction of the legal claim to a place in kindergarten in 1996, some municipalities were confronted with severe problems since they could not meet the increased demand for child care. This is why the German Federal Parliament (Deutscher Bundestag) adopted a legislative initiative proposed by the Federal Council of Germany (Bundesrat) that allowed communities to introduce day-of-birth cut-off rules for determining whether or not a child was eligible for public child care. Due to these cut-off rules, in an extreme case, children turning three years old right after the start of the kindergarten year could not enter kindergarten at the age of three but only one year later. These day-of-birth cut-off rules provide us with exogenous variation in attendance at German kindergarten, which we exploit in a 2SLS instrumental variable approach.

Drawing on the rich individual-level data of the German Socio-Economic Panel (SOEP), our instrumental variable estimations yield large and positive effects of public child care on maternal employment. Intention-to-treat estimates suggest that eligibility for public child care increases mothers' labor supply by 6 percentage points. Second-stage results show that if a mother's youngest child actually attends public child care as a result of the cut-off rule, this mother's probability of being employed increases by more than 35 percentage points. This also means that roughly two thirds of these mothers use child care for other reasons than being employed. Conservative back-of-the-envelope calculations suggest that more than 60 percent of the operation expenses of public child care (net of parents' fees) are covered by income taxes and

\footnotetext{
${ }^{1}$ Buechel and Spiess (2002) identify a significant positive association between regional public child care provision for three- to six-year old children and mothers' employment. Bick (2011) uses a micro simulation model to show that a lack of public child care in West Germany keeps women from labor market participation. In a recent paper on child care and child development, Felfe and Lalive (2012), in an aside, report some tentative evidence for positive effects of public child care on maternal employment. Finally, Gathmann and Sass (2012) analyze a reform in the East German state of Thuringia that increased prices for public daycare to find negative effects on female labor supply.
} 
social security contributions induced by the increase in maternal employment. Investigating the heterogeneity of our first-stage estimates, we show that the cut-off rules were mostly applied in West Germany during the first years after introduction of the legal claim to a place in kindergarten. The relevance of the cut-off rules becomes weaker with time since the reform and is virtually nonexistent in East Germany, where capacity constraints in public child care were not an issue. To investigate the validity of our instrumental variable approach, we run first-stage regressions in placebo treatment periods before 1996. Further, we perform placebo treatment tests drawing on the panel structure of the SOEP in which we investigate whether our instrument can predict maternal employment in the year preceding actual kindergarten entrance. All these specification tests corroborate the validity of our instrumental variable approach. In further robustness checks, we gradually restrict the sample to observations very close to the cut-off. Of course, the number of observations decreases resulting in large standard errors. But still, the point estimates are very similar to those estimated in the standard specification.

In a second identification strategy, we exploit the marked increase in public child care provision for three- and four-year old children in the years following introduction of the legal claim to a place in kindergarten. To this end, we use data from the German Micro Census, Europe's largest household survey. In a difference-in-differences approach, we compare the employment ratios of mothers with three- and four-year old children in 1996 and 2001 with the employment ratios of mothers with older children and, as an alternative, also the employment ratios of women without children. The difference-in-differences estimations confirm the large and positive causal effects of public child care on maternal employment. To provide evidence that the key identifying assumption of our difference-in-differences approach is met, namely, that the treatment and control group follow the same time trends in the absence of the treatment, we run a placebo treatment test in pre-treatment periods. These placebo treatment tests show that our treatment and control groups do indeed follow the same time trend in the years preceding the actual treatment; thus, they corroborate the key assumption of our difference-in-differences model. We find that the results from the difference-in-differences model using the German Micro Census are remarkably similar to the instrumental variable results using the SOEP, although we identify average treatment effects on the treated (ATT) in the difference-in-differences approach and local average treatment effects (LATE) for the complier subpopulation in the instrumental variables approach.

The reason for the fact that both approaches still yield very similar results could be that, in the end, in both identification strategies the same group of mothers is affected by the treatment, namely, those who have the opportunity to work because their three- or four-year-old child, who 
is also their youngest child, becomes eligible for public child care in a country where no market for private care exists. It is difficult to compare the size of the reduced form coefficients from the instrumental variable and the difference-in-differences models to the reduced form results of other studies because the size of the first stage might differ substantially across these studies. However, our second-stage instrumental variable effects can more easily be compared, and we find that the size of our effects is only slightly smaller than the effects of the introduction of free kindergarten in U.S. public schools on the labor supply of single mothers (Cascio 2009).

The rest of the paper is structured as follows. Section 2 summarizes the empirical literature on public child care and maternal employment. Section 3 describes the pre-reform setting as well as the 1996 public child care reform in Germany and explains how we exploit this reform in two quasi-experimental settings. Section 4 provides information on the rich individual level data sets of the SOEP and the German Micro Census that we use in our analyses. In Section 5, we present instrumental variable results using the SOEP data and corroborate these results applying difference-in-differences techniques on the German Micro Census. Section 6 concludes.

\section{$2 \quad$ Literature on public child care and maternal employment}

Earlier empirical studies on child care focused on analyzing the price of child care on mothers' employment. Reviews can be found in Blau (2003) and Blau and Currie (2006). Blau (2003) surmises that there is considerable uncertainty about the magnitude of the elasticity of mothers' employment with respect to child care prices. This uncertainty is partly due to at least questionable exclusion restrictions in these earlier non-experimental studies. The most reliable studies find only small effects of child care prices on mothers' labor supply.

A great deal of the current empirical literature on the effects of public child care on mothers' labor market outcomes apply quasi-experimental identification strategies using difference-in differences techniques or instrumental variable designs. The difference-in-differences studies on public child care and maternal employment often use differences in the expansion of publicly provided child care across regions within one country. For example, Havnes and Mogstad (2011) use registry data to analyze the introduction of subsidized universal child care for three- to sixyear old children in Norway from 1976 to 1979. In 1976, public child care coverage for three- to six-year old children was below 15 percent, while the employment rate of mothers of three- to six-year old children was 22 percent. Havnes and Mogstad (2011) find no positive causal relationship between public child care and mothers' employment. Note that even after the expansion in the late 1970s, public child care for three to six year olds was still severely rationed in Norway with a coverage rate of less than 30 percent. If mothers who were already closely 
attached to the labor market prior to the expansion received the rationed slots, they might just have substituted informal care for formal public child care, which could in turn explain the zeroeffect of public child care on maternal employment in this paper. In contrast, our paper investigates a setting where public child care was not rationed anymore after the cut-off age.

Cascio (2009) evaluates the introduction of free kindergarten for five year olds in U.S. public schools in the 1960s and 1970s using US Census data. In the late 1960s, roughly 30 percent of all five year olds were enrolled public school, whereas this number increased to just below 80 percent in 1980. However, also note that private care was comparable to public school care and affordable for many families. Prior to the policy initiative, the employment rate of single mothers whose youngest child was five was 58 percent, whereas the employment rate of married mothers whose youngest child was five was 36 percent. Cascio (2009) finds strong positive effects of the introduction of free kindergarten in U.S. public schools on the labor supply of single mothers whose youngest child was five (four out of ten enter the workforce), whereas effects for married mothers are zero.

Lefebvre and Merrigan (2008) use difference-in-differences techniques and exploit the stepwise introduction of universal child care arrangements for four to one year olds in the Canadian province of Quebec from 1997 until 2000. The price for these childcare slots was a mere five dollars a day. Prior to the reform, about 40 percent of all children up to four attended public child care, while the employment rate of mothers of these children was roughly 55 percent in Quebec. On the basis of Statistics Canada's Survey of Labor and Income Dynamics, the authors find that this universal child care program increased the labor market participation rate of mothers with at least one child age one to five by 8 percentage points. Baker et al. (2008) analyze the same reform using data from the National Longitudinal Survey of Children and Youth (NLSCY). Their difference-in-differences estimates confirm the positive and significant effects of inexpensive universal child care on mothers' employment.

Schlosser (2007) also uses difference-in-differences techniques to identify the effects of free universal preschool provision for three- to four-year olds on the labor supply of Arab mothers in Israel. Prior to the reform, labor force participation of Arab mothers of three to four year olds was as low as 6 percent in the treatment group. The public care enrollment rate for three year old children of Arab mothers was 21 percent prior to the reform, whereas the number was 32 percent for four year old children; enrolment in private care was about one percent. Using Data from the Israeli Labor Force Survey from 1998 to 2003, Schlosser (2007) finds positive effects of 
free universal child care on educated Arab mothers whose labor supply increases by 21 percentage points.

Difference-in-differences estimates of Berlinski and Galiani (2007) show that an Argentinan child care reform which provided free public preschool for three to five year olds induced an increase in labor supply of mothers in the mid to late 1990s. An increase in the new stock of rooms from zero to one, which corresponds to a situation where every child between three and five is in public preschool as compared to a situation without any public preschool, increases maternal employment by seven to 14 percentage points. The authors report average child care enrolment rates for three to five year olds of 43 percent in the period from 1994 to 2000, while the average employment rate of the respective mothers was 39 percent.

Lundin et al. (2008), in turn, exploit a Swedish child care reform from 2002 which reduced child care prices. While costs for child care amounted to ten percent of a household's net income in 2001, they were decreased to four percent in 2002. Using registry data from 2001 and 2003 and applying difference-in-differences techniques, the authors find zero effects of reduced child care prices on maternal employment. However, note that the child care attendance and maternal employment were at a very high level already before the reform. In particular, 83 percent of all three to six year olds and 60 percent of all one to two year olds attended child care institutions prior to the reform. The employment rate of mothers of three to six year olds was 82 percent and the employment rate of mothers of up to two year olds was 72 percent.

Nollenberger and Rodríguez-Plánas (2011) investigate the effects of a Spanish reform which introduced free public child care for all three year olds in 1991. They use data from the Spanish Labor Force Survey and exploit variation in public child care across time and Spanish states in a difference-in-differences setting. Prior to the reform, there was virtually no formal child care for three year olds in Spain, while we see universal and free preschool for four to five year olds. The employment rate of mothers with a three year old child was 29 percent in 1988, i.e., shortly before the child care reform. Nollenberger and Rodríguez-Plánas (2011) find that average employment of mothers of three year old children increased by 8 percent due to the introduction of free public child care for all three year olds. The effects are particularly strong and persist for several years for mothers with a high-school degree, whereas there are no effects for college educated mothers.

While the difference-in-differences framework is a very popular method of studying child care effects, an alternative strategy often applied relies on cut-off rules determining the eligibility for public child care. These cut-off rules are exploited in instrumental variable frameworks. Gelbach 
(2002) uses 1980 US Census data and exploits quarter-of-birth variation in the access to free public preschool for five year olds in the United States. He finds that public school enrolment of the child increases employment of mothers by four to five percentage points; there are no effects for single mothers if the five year old child is not the youngest child. In their data set, on average, 63 percent of five year old children who are the youngest child to a single mother attend public school, 16 percent attend private school. For married mothers, the respective numbers are 55 percent and 21 percent. The employment rate of single mothers whose youngest child is five is 70 percent while the respective number for married mothers is 58 percent. Similar to our setting, Gelbach (2002) not only has information on eligibility for child care but is also able to study (local) average treatment effects since he has data on preschool attendance by children.

The same is true for Berlinski et al. (2011), who exploit cut-off rules in admission to public child care for four year olds in Argentina using Argentine household survey data from the years 1995 to 2001. In 2001, child care enrolment of three to five year olds was 64 percent, while the authors present a discontinuous jump from 40 to 70 percent at the cut-off for four year olds. As an effect of the public child care admission cut-off, they find a jump in the employment rate of mothers of four year olds from 40 to 45 percent. Accordingly, 13 mothers start to work for every 100 youngest children starting preschool. However, there is no effect for mothers whose four year old child is not her youngest child. In contrast to Gelbach (2002), Berlinski et al. (2011) include only children born around the cut-off date for determining eligibility for child care, thereby avoiding the possibility that their estimates might be driven by age differences between children who are eligible for child care and those who are not.

Similarly, Fitzpatrick (2010) applies a sharp regression discontinuity design in which she can identify intention-to-treat effects (ITT), yet no (local) average treatment effects (LATE) of free universal preschool for four year olds in the US states Georgia and Oklahoma. This so-called Pre-K program increased statewide preschool enrolment by roughly 14 percent. Based on data from the 2000 Census, she finds little effects of free public preschool on the labor supply of most mothers. Still, for the subgroup of mothers from rural regions free preschool increases employment by 10 percentage points (or 20 percent). The average employment rate of mothers was 68 percent in Fitzpatrick's (2010) sample, while the author reports that 53 percent (46 percent) of all four year olds were enrolled in preschool in Georgia (Oklahoma). Bassok et al. (2012) suggest that the public Pre-K programs in Georgia and Oklahoma did not crowd-out private child care arrangements. Fitzpatrick (2010) argues that her zero effects on mothers' labor supply might be explained by the fact that female labor supply elasticities are smaller in recent 
years than they were in the past. Further, it should be noted that individuals in the control group might benefit from other child care subsidies such as Head Start.

Taken together, the current empirical literature on public child care and maternal employment suggests that marginal decreases in the costs of child care should not affect maternal labor supply if employment rates and child care attendance rates are already high. Further, we should not expect substantial employment effects if newly available public child care simply crowds-out existing private child care arrangements. Crowding-out might be particularly relevant if public child care slots are still severely rationed after expansion as in Havnes and Mogstad (2011). It might be that the newly provided public child slots are then primarily given to mothers already closely attached to the labor market, and that these mothers now just substitute private care with public care arrangements. Moreover, any effects of public child care on female labor force participation should be stronger for mothers whose youngest child is the marginal child who gets public care. If there are still younger children around, we do not expect strong effects on the respective mother's labor supply.

\section{The Expansion of Public Child Care in Germany as a Quasi-Experiment}

In this paper, we exploit the expansion of Germany's child care system in the late 1990s to identify effects of public child care on mothers' labor market outcomes. To establish causality, we need to overcome several econometric concerns. First, decisions about a mother's labor supply and her child's child care attendance are jointly determined. This simultaneity of mothers' choice about working and sending children to child care hampers causal identification of this relationship in simple OLS models (see, e.g., Coneus et al. 2009). Second, mothers who send their children to kindergarten could be systematically different from mothers who do not and these differences might also influence labor market outcomes. It is not possible to fully account for all these confounding factors and some will remain insufficiently observed or completely unobserved. However, special features of the politically induced expansion of the public child care system in Germany in the late 1990s provide us with two quasi-experimental settings that we exploit in order to identify causal effects of public child care on maternal employment.

\subsection{Child Care and Maternal Employment in Germany: the Pre-Reform Setting}

In our analysis, we focus on the system of German kindergarten, i.e., the publicly provided child care institution children voluntarily attend from age three until school entrance. In contrast to the United States, German kindergarten is not integrated into the school system and is entirely 
included in the child care system. ${ }^{2}$ The latter is historically characterized by large structural differences between West and East Germany (the former German Democratic Republic). In West Germany, child care was historically a private matter and the state was only marginally involved (Rauschenbach 2006). Mothers, grandparents, other relatives, and/or neighbors were the people chiefly responsible for the care of children from birth to school entrance. Most often, it was the mothers themselves who looked after their children (Tietze and Rossbach 1991). This stands in stark contrast to the situation in East Germany. Based on the socialist idea that education and care of children should be controlled by the state from the very beginning, the former German Democratic Republic (GDR) created an elaborate child care system offering full provision of institutional care for all children between one and six years old. This comprehensive child care system largely survived the reunification of East and West Germany and thus there continued to be substantial differences in public child care between the two parts of the country in the early 1990s.

After reunification in 1990, West Germany provided places in kindergarten to about 67 percent of children aged three to six, whereas there was full provision in the East German states (Rauschenbach 2006). There is substantial heterogeneity in child care attendance across children's ages in West Germany. Data from the German Micro Census suggest that, in 1995, 90 percent of all five and six year olds in West Germany attended kindergarten, whereas this number is only 60 percent for the four year olds and 30 percent for the three year olds. Further, public child care for under three year old children does virtually not exist in West Germany in the 1990s. Indeed, expansion of public child care for under three year olds did not start before the mid-2000s.

If we speak about kindergarten in West Germany, we usually mean half-day public child care for three to six year olds. Full-day public child care is very scarce in the 1990s; and even if a public child care institution offers to care for the children in the morning and in the afternoon, this mostly means that there is no care provided during lunchtime. For example, in 1989, only 14 percent of all kindergarten slots were full-time slots, and 62 percent of those did not offer care during lunchtime (Spieß 1998). Kindergartens are closed on weekends and during longer school holidays. Note that in West Germany, although kindergartens are not officially part of the educational system, they are often used for educational reasons even if the mother has no job.

We call child care institutions "public" if they receive public subsidies; subsidies can be received by public-sector as well as voluntary youth welfare organisations. In 1990, 30 percent of all child

\footnotetext{
2 To simplify matters, we will use child care and kindergarten as synonyms throughout the paper. This is unproblematic as we focus on only the care aspect of kindergarten. We are not interested in effects of possible skill accumulation during kindergarten or other quality aspects that would make the use of the notion preschool more consistent.
} 
care institutions for three to six year olds in West Germany were under the organization of public-sector authorities, i.e., municipalities, and 69 percent under the organization of youth welfare organisations. This means that 99 percent of all child care institutions in West Germany were publicly funded in 1990. Accordingly, there was virtually no private market for child care despite the fact that provision of child care was far from universal (Spieß 1998).

West Germany has long been known for its low female, and in particular maternal labor force participation. Data from the German Micro Census suggest that, in 1995, only 45 percent of all mothers whose youngest child was between three and four were employed. The employment rate of mothers whose youngest child was ten or eleven was slightly below 65 percent, while the employment rate for women without any children aged 29 to 36 was slightly above 85 percent. Thus, the employment gap between mothers of three to four year old children and women of a similar age but without any children amounted to 40 percentage points. Also note that two thirds of employment of mothers of three to four year olds is only part-time employment.

A further institutional detail, which might be worth mentioning in this context, is Germany's generous maternity leave regulation. After a series of expansions in leave coverage starting in the 1970s and continuing through the 1980s, mothers could benefit from job-protected leave for 36 months after birth and maternity leave payments for 24 months after birth from January 1993. Job-protected leave means that the employer must not dismiss a mother from the day she knows of the woman's pregnancy until 36 months after childbirth. While mothers received their average net pre-birth-income for the first two months after childbirth (or 600 Deutschmarks in case the mother did not work prior birth), maternity leave payments amounted to 600 Deutschmarks from the third month until the twenty-fourth month. In 1986, 600 Deutschmarks corresponded to roughly 25 percent of average pre-birth earnings. Ludsteck and Schönberg (2012) find that expansions in leave coverage had negative effects on labor market outcomes of mothers in the short run. However, they also show that these expansions did not affect long-run maternal labor supply measured six years after childbirth.

\subsection{The Introduction of the Legal Claim to a Place in Kindergatten}

The mid to late 1990s witnessed substantial political effort toward increasing public child care coverage in West Germany. One of the crucial reasons behind this effort was the increase in the number of well-qualified women who wanted to participate in the labor market. Women's increasing desire (or need) for labor force participation meant they were no longer so available as the answer to the question of who will care for children before they reach school entrance age. Thus, the trade-off between family or career being faced by young mothers revealed the 
insufficiency of the child care system and consequent economic and social problems. Contemporaneously, people started becoming aware of the importance of the early life period for child development, leading to an even stronger focus on better public care provision.

The crucial step toward full provision of public child care for three- to six-year olds in West Germany was the government's introduction of a legal claim to a place in kindergarten (Rechtsanspruch auf einen Kindergartenplatz), which became effective on $1^{\text {st }}$ August 1996. Since that year, every child has been eligible to attend a center-based kindergarten from his or her third birthday until school entrance. ${ }^{3}$ The legal claim is found in $\$ 24$ SGB VIII (Achtes Buch Sozialgesetzbuch) and covers highly subsidized half-day care. To meet the increased demand for public child care created by this law, a substantial and rapid expansion of center-based care places became necessary. On average, roughly 80 percent of the costs of a place in public child care were covered by subsidies, with the remaining 20 percent financed by parents' child care fees (Statistisches Bundesamt 2004). Altogether, the German government spent 10.5 billion Euros on public child care in 2002, 10 billion of which were spent on operating expenses and the remaining 0.5 billion on investments. ${ }^{4}$ Note that the official statistics only include government spending aggregated over all forms of public child care; however, kindergarten care was by far the most prominent expense.

Due to the complicated organizational system in Germany, implementation of the legal claim to a place in kindergarten turned out to be a difficult process. The new law had been passed at the federal level, but it was the states and, especially, the municipalities that were responsible for organizational and financial implementation of it. Decision makers at the municipal level were confronted with completely new responsibilities and were unable to quickly meet the new and officially mandated demand for child care supply. As a consequence, by the end of 1995, the German Federal Parliament (Deutscher Bundestag) adopted a legislative initiative proposed by the Federal Council of Germany (Bundesrat) that introduced cut-off rules: municipalities could decide that children will not necessarily enter kindergarten by their third birthday, but will instead start kindergarten in the year following their third birthday. The start of a kindergarten year typically coincides with the start of a school year, which is in August or September. ${ }^{5}$ So, children born after the cut-off date had, at worst, to wait almost a year to actually start kindergarten. This

\footnotetext{
${ }^{3}$ The claim was originally formulated as a social measure accompanying a new abortion regulation in Germany and intended to encourage mothers to carry children to term.

${ }^{4}$ As a comparison, government spending on universities amounted to 19.5 billion Euros in 2001 .

${ }^{5}$ Although the start of the kindergarten year is not completely restricted to a specific date and generally possible in every month, most children enter kindergarten at the start of the kindergarten year.
} 
rule relieved some of the pressure on municipalities as it gave them some extra time to provide the child care supply required by the new law.

The cut-off rule was intended as a temporary measure and the period of its applicability should have ended at the end of 1998 (see Bundesgesetzblatt 2010, p. 3022); however, the use of cut-off dates for child care entrance continued to be common practice until quite recently. When looking at child care attendance rates for the different age cohorts from three to six, we still find the lowest rates for three-year-old children (Konsortium Bildungsberichterstattung 2006, p. 38). According to the 12th Kinder- und Jugendbericht (BMFSFJ 2005, p. 298), this is partly attributable to supply-side shortages and the ongoing use of cut-off rules in several municipalities.

The cut-off rule was not enforced universally as some municipalities had child care supply sufficient to provide for all children aged three up to the age school entrance and did not need the rule. Moreover, some families might have been able, for various reasons, to place their children in child care at the age of three or even earlier even though the children, to be in compliance with the rule, should have been older when entering. Other mothers preferred to care for their children themselves and therefore decided to delay kindergarten entrance until their children were older, completely irrespective of the rule.

\subsection{Empirical Strategies}

\section{Instrumental Variable Approach}

Unfortunately, there are no data on which municipalities adopted cut-off rules in which years. However, the mere existence of these cut-off rules provides us with a quasi-experimental setting that can be exploited in an instrumental variable approach. This is because the cut-off rules create variation in child care attendance that is reasonably exogenous to confounding factors determining child care and mothers' labor market participation simultaneously. We instrument actual child care attendance $D_{i}$ with the eligibility $Z_{i}$ at the last kindergarten start. Our quarter-ofbirth style instrument $Z_{i}$ is a dummy variable indicating whether a mother's youngest child was above cut-off age ( $>=36$ months) at the last kindergarten start and was therefore eligible for child care. This leads to the following model predicting actual public child care attendance:

$$
D_{i}=\mu+\delta Z_{i}+\phi X_{i}+\chi_{i}
$$

The coefficient $\delta$ on $Z_{i}$ shows the relevance of our instrument and indicates the share of children who enter kindergarten in compliance with the cut-off rule; $\mathrm{X}$ is a vector of covariates 
and $\chi$ is the error term. ${ }^{6}$ We use the predicted values $\hat{D}_{i}$ from Equation (1) in Equation (2) to obtain a local average treatment effect (LATE) $\tau$ of public child care attendance of the youngest child on mothers' labor market outcomes, while $\mathrm{X}$ is a vector of covariates and $\pi$ is the error term:

$$
Y_{i}=\eta+\tau \hat{D}_{i}+v X_{i}+\pi_{i}
$$

In other words, the cut-off rule creates a discontinuous jump in kindergarten attendance at the age threshold of 36 months. We use this exogenous variation in public child care attendance $\mathrm{D}_{i}$ that is due to the age cut-off rule $Z_{i}$ in order to estimate the effect of kindergarten attendance on maternal employment. In order for $\tau$ to be interpreted in a causal way, our quarter-of-birth-style instrument $Z_{i}$ (cf. Angrist and Krueger 1991) must meet the exclusion restriction. This means that the cut-off rule must not affect maternal employment directly nor via any other channel but kindergarten attendance. Of note is that our cut-off rule instrument violates the exclusion restriction if the age of the youngest child has a direct effect on maternal employment or an indirect effect on maternal employment running via channels other than child care. For example, there could be an indirect effect if informal caregivers such as grandparents, friends, or neighbors can more easily care for slightly older children (just above three years old) than for younger children (just below three years olds), which, at the same time, could make maternal employment more likely. Further, mothers' attitudes toward career and family life could change with the youngest child's age. In this case, the exclusion restriction in a model that does not control for age would be violated if, as the youngest child grows older, mothers are more likely to opt for child care and simultaneously become employed. This is why we explicitly include the age of the youngest child (in months) as a covariate in our instrumental variable approach. To check the robustness of our results, we not only control for the youngest child's age (in months) linearly but also include the square term of the child's age. In addition to the child's age, we can control for several demographic and socioeconomic characteristics of the mother (age, highest educational degree, migration status) and of her partner (age, highest educational degree, migration status, employment status, labor income). Likewise, we include information about the household size, the youngest child and his or her siblings (youngest child's gender, number of siblings, and distance in months to oldest sibling), and state and year dummies.

\section{Difference-in-Differences Approach}

\footnotetext{
${ }^{6}$ In all our IV regressions, standard errors are clustered at the individual mother level; clustering the standard errors by the child's age does hardly change the results; if at all, standard errors slightly decrease.
} 
Introduction of the legal claim to a place in kindergarten led to a substantial expansion of child care facilities, particularly in West Germany, in the late 1990s and early 2000s. Figure 1 shows the development of child care attendance in West Germany from 1991 to 2003. ${ }^{7}$ Child care attendance by five- and six-year old children was already at the high level of slightly under 90 percent in 1991 and remained relatively stable throughout the following years. Three- and fouryear old children, in contrast, were substantially less likely to attend child care in the early 1990s. However, from 1996 to 2001, child care attendance by three- and four-year-old children increased sharply. We exploit the considerable rise in public child care attendance by three- and four-year-old children in West Germany in our second identification strategy by applying difference-in-differences techniques.

\section{Figure 1 about here}

To this end, we define mothers whose youngest child is three or four years old as our treatment group. As a control group, we use mothers whose youngest child is aged 10 or 11 years. ${ }^{8}$ Since these older children were attending school during the whole period of observation, they were not affected by the legal claim to a place in kindergarten. There was also no school reform (e.g., an expansion of all-day schools) or any change in the provision of after-school care that might have influenced the time these older children were exposed to public care arrangements (including schools). As an alternative control group we use women without children. We identify the treatment effect by computing the difference in the employment trend from 1996 to 2001 between mothers with three- to four-year olds and mothers with 10- to 11-year olds (or mothers without children) in West Germany. The treatment effect $\theta$ can be expressed by the following double difference equation:

$$
\begin{aligned}
& \theta=E\left[Y_{i}(1)\right]-E\left[Y_{i}(0)\right]= \\
& \left\{E\left[Y_{i} \mid T_{i}=1, D_{i}=1\right]-E\left[Y_{i} \mid T_{i}=0, D_{i}=1\right]\right\}- \\
& \left\{E\left[Y_{i} \mid T_{i}=1, D_{i}=0\right]-E\left[Y_{i} \mid T_{i}=0, D_{i}=0\right]\right\},
\end{aligned}
$$

where $E[\cdot]$ is the expectation operator and $Y_{i}$ is the labor market outcome of mother i. $D_{i}=0$ for the control group of mothers with the youngest child aged between 10 and 11 years, and $D_{i}=1$ for the treatment group of mothers with three- to four-year-old children. $T_{i}=0$ for the

\footnotetext{
${ }^{7}$ We observe few dynamics and universally high attendance in child care by all children between the ages of three and six in East Germany, as can be observed in Figure A.1 of the Appendix.

${ }^{8}$ Using mothers with five- or six-year-old children as a control group would lead to spurious results since this group could benefit from the legal claim to a place in kindergarten. For example, a child who was five year old in 2001 was three years old in 1999 and thus part of the treatment group. This would violate the standard stable unit treatment value assumption (SUTVA) (Rubin 1978).
} 
year 1996 , and $T_{i}=1$ for the year $2001 .^{9}$ In a multivariate setting, the treatment effect $\theta$ is identified as the coefficient on the interaction term between $\mathrm{D}$ and $\mathrm{T}$ in the following regression:

$$
Y_{i t}=\sigma+\omega T_{t}+\vartheta D_{i}+\theta\left(T_{t} D_{i}\right)+\varepsilon_{i t}
$$

$\omega$ captures time effects common to the treatment and control group, $\vartheta$ captures baseline differences between the treatment and control group, and $\mathcal{E}$ is the error term. The inclusion of further covariates in this model is straightforward. Instead of merely looking at two years, 1996 and 2001, we additionally estimate an extended version of Equation (4) to illustrate the development of maternal employment over the whole period from 1996 to 2001.

The key identifying assumption of this difference-in-differences estimation strategy is that the treatment and control group follow the same employment trends in absence of the treatment. In other words, there are no unobserved variables that change over time and have differential effects on the labor market outcomes of mothers with children aged three or four as compared to mothers with children aged 10 or 11 (or women without children). A simple way to test the plausibility of this assumption is a placebo treatment test in the years preceding the actual treatment that can show deviations from the common trend in pre-treatment years. In the posttreatment years, the only reason why the trend of the treatment group departs from the trend of the control group must be the treatment. This assumption would obviously be violated if there was another policy reform which affected treatment and control group differently. To the best of our knowledge, no such policy occurred in the post-treatment years. Still, one might argue that maternity leave expansions in the 1980s and early 1990s (the last one was in January 1993) could be a threat to identification. In particular, the control group of mothers of ten to eleven year olds in 2001 had benefitted from more generous maternity leave coverage than mothers of ten to eleven year olds in 1996. If extended maternity leave had negatively effects on mothers' labor supply, this would negatively affect the trend in the control group and thus bias our difference-indifferences estimates upwards. However, Ludsteck and Schönberg (2012) find that maternity leave expansions did not affect mothers' long-run labor outcomes, measured six years after childbirth. Thus, it seems justified to assume that maternity leave expansions did also not affect mothers' labor outcomes measured ten to eleven years after childbirth. ${ }^{10}$

\footnotetext{
${ }^{9}$ We use the year 1996 as the pre-treatment year, since the Micro Census data we use for this approach are collected in spring whereas the legal claim was introduced in August 1996.

${ }^{10}$ Furthermore, we do not find any evidence for fertility effects of the child care reform, which would lead to selective sampling of the control group. Indeed, mothers in our sample whose children are eligible for kindergarten do not differ by the number of children observed in their last available SOEP interview from mothers whose children are not eligible for kindergarten.
} 


\section{Data on Child Care Attendance and Maternal Employment}

To identify the causal effect of child care attendance on maternal labor supply, we draw on two different individual-level data sets. For our instrumental variable approach, we use the German Socio-Economic Panel (SOEP); the difference-in-differences estimations are based on data from the German Micro Census, Europe's largest household survey.

\subsection{The German Socio Economic Panel (SOEP)}

The SOEP is a representative and longitudinal household survey that provides annual information about households and their members on a wide range of socioeconomic and demographic characteristics. The survey started in West Germany in 1984; since 1991, it has been extended to East German households. A feature of the SOEP making it possible to link mothers to their children and, at the same time, to their partners enables us to characterize families along many socioeconomic and demographic dimensions.

For our instrumental variable approach, it is especially important to have information about child care attendance and, most crucially, about the month of birth of the children. Since we know the month of the interview, we can compute the age of a child in months at the time of the interview and also at the time of the start of the last kindergarten year. We use two outcome variables measuring maternal employment. The first is a dichotomous variable that equals 1 if the mother is working; 0 otherwise. The second is a variable that measures a mother's weekly working hours. We include an extensive set of covariates in our model to capture various aspects of the household's socioeconomic situation. Specifically, we use information on the mothers' age, years of education, and migration background, as well as information about their partner's age, years of education, migration background, occupational status, and labor income. We also know whether the family owns or rents the flat/house in which they live and in which state of Germany this flat/house is located. Furthermore, we use variables that characterize the children, such as age, gender, number of siblings, and age of siblings. Finally, we include year dummies to capture yearspecific effects.

\section{Figure 2 about here}

SOEP interviews take place throughout the year, but the majority of them are conducted in the spring. If children are in child care at the month of the interview, we assume that they have been in attendance since beginning of the last school year in their federal state of residence. ${ }^{11}$ This

\footnotetext{
${ }^{11}$ School begins at various times between August and September, depending on the state. We have exact information on the date school begins in each German state for the whole sample and can link this to our household data.
} 
allows us to compute the age in months at the last possible school start, both for children who attend and for those who do not. While we cannot completely rule out that children do not enter at other dates during the year, we are confident that most children's kindergarten start coincides with the start of the school year. Schlotter (2011) shows with data from the Children's Panel of the German Youth Institute (DJI-Kinderpanel) that almost two-thirds of all children report entrance in August or September. Entrance in other months is almost equally distributed at a level of about 5 percent (see Figure 2).

By using the SOEP waves from 1991 until 2005 in our estimations, we can not only analyze an extensive period after introduction of the legal claim to a place in kindergarten, but also several years before this reform, which should give us a comprehensive picture of the effects of this reform on maternal employment. We limit our sample to mothers whose youngest child was born between 1992 and 2000 as these cohorts are the ones most likely affected by the cut-off rules introduced in 1996. Furthermore, we only include mothers whose youngest child, born between 1992 and 2000, was at least 36 months old at the time of the interview and at most 48 months old at the last possible kindergarten start. Thus, we focus precisely on the group of children whose child care attendance was dependent on the existence of a cut-off date. Moreover, note that this restriction ensures that maternity leave has already expired for all mothers in our sample. Furthermore, excluding mothers with children younger than 36 months seems reasonable since the presence in the household of a very young sibling might prevent mothers from entering the labor market, irrespective of the child care attendance of their older child. As most interviews take place half a year after kindergarten start, we allow for an interval long enough to give the mother a chance to search for and find a suitable job. The full sample consists of 1,228 mothers and 1,936 mother-child observations.

\subsection{The German Micro Census}

We also use data from the German Micro Census, the largest household survey in Europe. This data set provides annual information on a representative 1 percent sample of the German population with a focus on demographic and labor market relevant variables. ${ }^{12}$ Entire households are sampled, enabling us to observe both mothers and their children. We use the Micro Census waves 1991, 1993, 1995, and 1996 until 2001. ${ }^{13}$ The census data do not provide information as detailed as that we obtain from the SOEP; in particular, the children's months of birth are not observed. Yet, the larger number of observations of the Micro Census and the availability of

\footnotetext{
${ }^{12}$ The Scientific Use Files that we can use are a 70 percent subsample of the original 1 percent Micro Census sample.

${ }^{13}$ Unfortunately, the Scientific Use Files for the Micro Census waves 1992 and 1994 are not available and we have to use the incomplete times series of 1991, 1993, and 1995 to study pre-reform trends.
} 
variables such as a mother's employment status and child care attendance of the children (as well as several additional covariates), which can be observed in all waves and are comparable over time, make this data set a complement to the SOEP data. In each of the Micro Census crosssections, we focus on households with mothers whose youngest child is three or four years old, since this is the group of families affected by introduction of the legal claim to a place in kindergarten in August 1996 and the massive expansion of public child care in subsequent years. As with the SOEP, using only families whose youngest child is three or four years old ensures that mothers' employment outcomes are not influenced by the presence in the household of an even younger child. As a control group we use mothers whose youngest children are 10 or 11 years old and thus do not benefit from the increased supply of public child care in the years after 1996. Alternatively, we use women without children as our control group.

Mothers report whether they are employed and, if so, whether they work full or part time. ${ }^{14}$ In addition, the data set contains a variable that assesses child care attendance by the children (reported by the head of the household) at the time of the interview. ${ }^{15}$ In our estimations we can also include several covariates, such as nationality, age, and highest school degree of the mother, as well as the youngest children's age distance (in years) from their oldest siblings. Information on state of residence of the household and on family type facilitates separate analyses for East and West Germany, as well as for single mothers and mothers with partners, respectively.

\section{$5 \quad$ Results}

In what follows, we provide evidence on the effects of public child care on mothers' labor market outcomes from the instrumental variable and the difference-in-differences approach.

\subsection{Results from an Instrumental Variable Approach}

We start our instrumental variable approach by plotting kindergarten attendance rates by the child's age (in months) at the start of the last kindergarten year. Note that kindergarten attendance is measured in spring, i.e., roughly half a year after the kindergarten year started. Figure 3 shows that, in general, the older the child at the start of the last kindergarten year, the more likely she is to attend kindergarten roughly half a year later. Our instrumental variable

\footnotetext{
${ }^{14}$ The definition of employment in the Micro Census is quite broad and includes people who are in vocational training, who are marginally employed, those working to supplement their welfare benefits, and the like.

${ }^{15}$ The Micro Census question only asks whether the child attends public child care or not and thus does not allow us to differentiate by public child care facility for different age groups (Kinderkrippe for those aged zero to three years, Kindergarten for three- to six-year old children, and Kinderhort for after school care for students). However, since we know the age of the children, we can clearly identify child care attendance by children aged three and four as kindergarten attendance, which is the child care facility we are interested in due to its expansion in 1996 and subsequent years.
} 
approach exploits the fact that kindergarten attendance sharply increases at the cut-off age of 36 months indicated by the vertical red line. Whereas 61.5 percent of the children aged 35 months at the start of the last kindergarten year attend kindergarten half a year later, this number jumps to 78.5 percent for children aged 36 months at the start of the last kindergarten year. This 17 percentage point difference between children who differ by just one month in age corresponds to a substantial increase of kindergarten attendance by 28 percent.

Figure 3 about here

Column 1 of Table 1 sets out descriptive statistics of mothers whose youngest child was 36 months or older at the time of the last kindergarten start (in August or September) and thus eligible for child care due to the cut-off rules. We compare these statistics to those of mothers whose youngest child was slightly younger than 36 months at the time of the last kindergarten start and thus not eligible for child care (Column 2 of Table 1).

As seen from Table 1, the groups are not statistically different in terms of mothers' characteristics (such as years of schooling, migration background), partners' characteristics (years of schooling, employment status, labor income, migration background), and other child and family characteristics (youngest child's gender, number of siblings, child's distance to oldest sibling in months, number of household members). This provides first support for the validity of our identification strategy, which relies on the assumption that the groups systematically differ in eligibility for child care but not in other socioeconomic characteristics. Virtually the only variables where we find, by mere construction, significant differences between the groups are the age variables, i.e., mothers' age, partners' age, and age of the youngest child. To avoid the possibility that pure maturity effects are driving our results, we control for these age variables in our 2SLS estimations. Further, we also include all the other variables reported in Table 1 as covariates in our multivariate instrumental variable framework.

\section{Table 1 about here}

Turning to a multivariate setting, we start by estimating first-stage regressions predicting child care attendance $\mathrm{D}$ of the youngest child at the time of the interview by our cut-off rule $\mathrm{Z}$ and a vector of covariates $\mathrm{X}$ (see Equation (2)). Column 1 of Table 2 shows the results of a regression of kindergarten attendance on the cut-off rule instrument where we only control for the youngest child's age (in months). We can confirm that our instrument is indeed a strong and relevant predictor of actual child care attendance. Eligibility due to the cut-off rule increases the probability of child care attendance of the youngest child by 17.8 percentage points. This first 
stage effect turns out to be virtually unaffected by the inclusion of all the individual level controls presented in Table 1 as well as state and year fixed effects (Column 2 of Table 2).

During its socialist years, East Germany developed one of the most advanced child care systems in the world, which, by and large, continued to exist after German reunification. As a consequence, in East Germany, child care was already available for very young children (i.e., those far below the age of three) in the late 1990s. In West Germany, however, we child care for children below the age of three was very scarce during our period of observation. Therefore, we expect the age cut-off rule to be more relevant for West German than for East German mothers and when we run our first-stage regressions separately on the subsamples of East and West German mothers, we see that this is, indeed, the case (Columns 3 and 4 of Table 2).

The age cut-off rule was most often applied during the first years after introduction of the legal claim when there was often a severe shortage of child care places for three- to six-year-old children. However, cut-off dates continued to be used in many municipalities until quite recently (BMFSFJ 2005), even though supply-side shortages are no longer much of an issue. We split the sample into two subsamples, one of them covering the years from 1996 to 2000, the other covering the years from 2000 to 2005. We expect the first stage to be stronger in the first years after the reform, and weaker, though still present, in the later years. Indeed, as we observe in Columns 5 and 6 of Table 2, the coefficient of the cut-off rule instrument is substantially larger in the years from 1996 to 2000 than in the years from 2000 to 2005.

\section{Table 2 about here}

Our instrument is designed to reveal effects of the cut-off rules applied in the aftermath of introducing the legal claim to a place in kindergarten in 1996. Therefore, we should not see any correlation between our instrument and child care attendance before 1996. We test this by estimating our first-stage regression (Equation (2)) on a sample of mothers whose youngest child was slightly below or slightly above the cut-off age of 36 months at the start of the last kindergarten year in the years 1991 to 1995. As expected, Column 7 of Table 2 shows that our instrument does not predict actual child care attendance in these years.

In further first stage regressions, which are available from the authors upon request, we analyze heterogeneity in the first stage effects along several characteristics of the mother, her partner and the family. This gives us some idea about the composition of the complier subpopulation for which our instrumental variable estimates identify treatment effects. In particular, we run the first stage regressions on specific subsamples and compare the size of the first stage coefficients to 
each other. It turns out that mothers with above median years of schooling, mothers with above median age, mothers also having older children as well as mothers whose oldest child is already above median older than her youngest child more strongly react to the eligibility cut-off,

Let us now turn to our main outcome variable, which is maternal employment measured roughly half a year after kindergarten start. Figure 4 plots maternal employment rates by the age of the youngest child (in months) at the last kindergarten start. Thus, Figure 4 boils down to a graphical representation of the intention to treat effects (ITT). The vertical red line again marks the age cut-off, which marks the 0 to 1 change in our instrument. We can see that, in general, the older the child at the start of the last kindergarten year, the more likely her mother ii is that her mother is employed half a year later. Most importantly, however, we observe a jump in employment at the cut-off age of 36 months indicated by the vertical red line. While 48.7 percent of all mothers whose youngest child was 34 or 35 months at the start of the last kindergarten were employed half a year later, this number jumps to 56.3 percent for mothers whose youngest child was 36 or 37 months old at the start of the last kindergarten year. Thus, employment increases by 7.6 percentage points or 15 percent at the kindergarten eligibility cut-off.

\section{Figure 4 about here}

We now estimate ITT effects from a reduced form regression, where we regress a mother's labor market outcomes $\mathrm{Y}$ on our age cut-off instrument $\mathrm{Z}$. In addition to these ITT estimates, we also present results from 2SLS regressions where we use only the exogenous part in the variation of child care attendance that is determined by our age cut-off rule instrument (see Equation (2)). This allows us to identify the causal effect of the youngest child attending child care on maternal labor supply Y for the complier subpopulation. In all regressions, we first only control for the youngest child's age in months. In a second step, we then include the full set of control variables $\mathrm{X}$ (mother's age, years of schooling, and migration background; partner's age, years of schooling, migration background, employment status, and net labor income, the size of the household, the youngest child's age and gender, number of siblings, and distance (in months) to his or her oldest sibling; as well as state and year dummies).

Table 3 reports results for our dichotomous outcome variable maternal employment. Columns I through III present the estimates where we only control for the youngest child's age in months, while we include the full set of control variables X in Columns IV through VI. The reduced-form estimate in Column I shows that eligibility for child care increases a mother's probability of being employed by 6.4 percentage points. If we include state and year fixed effects as well as all our individual level controls, the ITT estimate remains virtually unaffected: eligibility for child care 
increases a mother's probability of being employed by 6.5 percentage points (Column IV of Table 3). The first-stage estimates in Columns II and IV of Table 3 have already been presented in Table 2. As we can again see, these estimates are unaffected by the inclusion of the full set of control variables. Moreover, the results confirm that our cut-off rule instrument is highly relevant and does not suffer from weak instrument problems (with robust F test statistics of 30.2 and 37.5, respectively). Since the reduced form as well as the first stage estimates are unaffected by the inclusion of control variables, it is not surprising to see that so are the second stage estimates. Columns VI of Table 3 suggests that child care attendance by the youngest child causally increases the probability of the mother being employed by 36.6 percentage points. On the other hand, this also means that roughly two thirds of these mothers use child care for other reasons than being employed. This effect is very similar to the effects of the introduction of free kindergarten in U.S. public schools on the labor supply of single mothers (Cascio 2009).

In Table 4, we run the same exercises for our alternative outcome variable weekly working hours. Again, Columns I through III present the estimates where we only control for the youngest child's age in months, whereas we include the full set of control variables $\mathrm{X}$ in Columns IV through VI. Once more, the inclusion of the full set of control variables leaves the ITT and 2SLS estimates virtually unaffected. From Column IV of Table 3 we can see that eligibility for child care results in an average increase of 2.5 working hours per week. The first-stage estimate from Columns V of Table 4 again proves that our age cut-off instrument is highly relevant and does not suffer from weak instrument problems (with a robust F test statistic of 32.4), while the second-stage estimates show that child care attendance by the youngest child causally increases working hours per week by 14.3 (Column VI of Table 4). Thus, our multivariate 2SLS estimates yield a large and positive effect of public child care on maternal employment. ${ }^{16}$

In order to get still more feeling for the size of the estimated effects, we once again turn to the ITT estimates from Column IV of Table 3 and Column IV of Table 4. Relating these coefficients to the mean value of the respective outcome variable for the group of mothers having the instrument switched off, we find that the intention-to-treat effects correspond to an increase of maternal employment by 14.1 percent and an increase of working hours by 23.2 percent. These results suggest that public child care has not only positive effects at the extensive but also at the intensive margin.

\section{Table 3 about here}

\footnotetext{
${ }^{16}$ In additional estimations presented in Table A.2 of the Appendix, we included mothers with partners as well as single mothers in our sample, dropped all partner covariates, and added a dummy indicating whether or not a mother is a single mother. The results are not different from those presented in Table 3 and Table 4.
} 
The panel structure of the SOEP allows us to perform yet another specification test. If the coefficients estimated in Table 3 and Table 4 do indeed reveal the causal effect of public child care in kindergarten, we should not see any effects of public child care in period $t$ on maternal employment in period t-1. To test this prediction, we run our reduced-form and 2SLS models with a minor modification, namely, that we now use a mother's employment status in $t-1$ and weekly working hours in $t-1$, respectively, as our outcome variables. The results of this placebo treatment test are shown in Table 5. As expected, we find no significant effects of public child care in $t$ on maternal employment in $t-1$. Indeed, the point estimates are not only far from being statistically significant, they are slightly positive in the employment equation and slightly negative in the weekly working hours equation, albeit always close to zero. This shows that mothers whose youngest child turned three shortly after the cut-off date are not different from mothers whose youngest child turned three shortly before the cut-off date in terms of employment before the cut-off rule becomes actually relevant. Thus, this placebo treatment test corroborates the validity of our instrumental variable approach.

\section{Table 5 about bere}

Table A.3 of the Appendix provides the results of further 2SLS regressions where we gradually restrict the sample to observations close to the eligibility cut-off. In particular, in Columns I and II we only use observations of mothers whose youngest child is between 30 and 42 months old at the start of the last kindergarten year, in Columns III and IV the sample consists of mothers whose youngest child is between 32 and 40 months old at the start of the last kindergarten year, whereas in Columns V and VI, we restrict the sample to mothers whose youngest child was between 34 and 38 months old at the start of the last kindergarten year. Of course, observation numbers substantially decrease in these exercises. Accordingly, also the precision of the estimates from Table A.4 clearly deteriorates. However, it is reassuring to see that the point estimates still depict large and positive effects of public child care attendance on maternal employment; indeed, the point estimates fluctuate around the coefficient estimated on the full sample. ${ }^{17}$

Taken together, our 2SLS estimates suggest that child care attendance has large and significantly positive causal effects on mothers' employment probability and on their weekly working hours. Thus, public child care is not a mere substitute for other informal child care arrangements in

\footnotetext{
${ }^{17}$ In a related robustness check, we additionally included the square of the age of the youngest child in months as a control variable. The point estimate on public child care gets insignificant due to large standard errors. Yet, the point estimate even gets slightly larger.
} 
Germany. This result is also supported by additional instrumental variables estimations which show that public child care indeed reduces the mother's time used for child care by roughly four hours a day. ${ }^{18}$ Yet, standard errors are typically large in 2SLS estimates, especially with a relatively low number of observations. Despite the low number of observations, the SOEP is the best data available for our 2SLS estimations since we need exact information on the month of birth of a child, which is not available in the German Micro Census. However, we can use the large samples of the Micro Census in a difference-in-differences approach, which gives us another opportunity to identify causal effects of public child care on maternal employment. The results of this alternative approach are presented in the next section.

\subsection{Results from a Difference-in-Differences Framework}

Between 1996 and 2001, there was a considerable increase in kindergarten attendance, from 53 percent to 70 percent, by three- and four-year-old children whereas kindergarten attendance for five and six year old children remained flat at a high level of 90 percent (Figure 1). ${ }^{19}$ After 2001, the expansion of public child care places for three to four year olds stopped. In line with this observation, we use the Micro Census waves 1996 and 2001 for our basic difference-indifferences estimations. We define 1996 as the pre-treatment year and 2001 as the post-treatment year. Mothers whose youngest child is three or four years old constitute our treatment group. As a control group, we use mothers with a youngest child aged 10 or 11 years and, as an alternative, two different groups of women without children. First, we use the group of all women aged between 18 and 60 without children. As an additional control group, we restrict the subsample of women without children to women aged 29 to 36 years; in terms of age, these women are comparable to our treatment group since they are in the two middle quartiles of the age distribution of mothers with children aged three or four. In each wave we observe more than 5,000 mothers whose youngest child is three or four years old (treatment group), more than 4,000 mothers whose youngest child is aged 10 or 11, more than 49,000 women aged 18 to 60 years without children, and more than 7,000 women aged 29 to 36 years without children (control groups). Table A1 sets out descriptive statistics for the treatment group and all control groups, both for the pre-treatment year 1996 as well as the post-treatment year 2001.

Figure 5 shows the development of women's employment over time for the treatment and control groups in West Germany. While employment levels obviously differ for our treatment and control groups, the pre-treatment trends from 1991 to 1996 are nearly identical across all

\footnotetext{
18 The results from these regressions are available from the authors upon request.

${ }^{19}$ As already noted earlier, formal child care for under three year olds was virtually non-existing in West Germany in the 1990s. Indeed, expansion of formal child care for under three year olds did not start before the mid-2000s.
} 
groups of women. After 1996, we observe a similar increase in employment for our control groups of women without children and women whose youngest child is aged 10 or 11. In contrast, the rise in employment for mothers of children aged three or four years—our treatment group-is considerably larger. To highlight this relative increase in employment for our treatment group, we added a dashed line to Figure 5 that shows the counterfactual development of the treatment group had it not been treated. This counterfactual trend is the parallel shift of the employment development of mothers with 10- or 11-year-old children by the 1996 baseline difference in employment between this group and our treatment group. In other words, we assume that the pre-treatment-difference in employment between treatment group and control group would have been stable in subsequent years in absence of the treatment. We clearly observe that the increase in actual employment for our treatment group is more pronounced than is predicted by the counterfactual trend, which provides graphical evidence of a causal effect of public child care on maternal employment.

\section{Figure 5 about here}

In Columns 1, 3, and 5 of Table 6 we provide the basic difference-in-differences estimates that exactly correspond to the differences in employment development between the treatment and the various control groups as shown in Figure 4. The coefficient on the interaction term (After treatment $*$ Treatment group) corresponds to the treatment effect $\theta$ of Equation (4). In line with Figure 3, we find a significant positive effect of the increase in public child care between 1996 and 2001 on the employment of mothers of three- and four-year-old children ranging from 5.2 to 8.7 percentage points. Controlling for additional covariates in Columns 2, 4, and 6 does not significantly change the estimates compared to the respective baseline results in Columns 1, 3, and 5. Taking into consideration that public child care coverage for our treatment group increased from 55 to 70 percent from 1996 to 2001, the interpretation of these coefficients is straightforward: relying on the rather conservative estimates from Column 2, for example, a 10 percentage point increase in public child care coverage for three- to four-year olds leads to a 3.5 percentage point increase in employment of mothers of three- to four-year-old children. This estimate is very close to the 2SLS results, where we find that a 10 percentage point increase in public child care coverage leads to a 3.7 percentage point increase in maternal employment.

\section{Table 6 about here}

We also estimated a difference-in-differences model showing the stepwise increase of maternal employment in the years from 1997 to 2001, which goes hand in hand with the gradual increase in child care coverage. The results of this estimation can be found in Table A.4 of the Appendix. 
Furthermore, we ran the difference-in-differences regressions for mothers with partners and single mothers separately and found no clear and substantial heterogeneity although the point estimates tend to be larger for single mothers than for mothers with partners. The results of these additional estimations can be found in Table A.5 of the Appendix.

Deviations from a common trend between treatment and control groups in the years preceding the actual treatment would make questionable the validity of our difference-in-differences approach. The largest threat to our identification would be if mothers with children aged three or four become more eager to enter the labor market and if it this eagerness that led to child care expansion in the years after 1996. To assess the validity of the key identifying assumption of our difference-in-differences approach, namely, that the time trends are the same for treatment and control groups in absence of the treatment, we conduct placebo treatment tests in the pretreatment periods. More precisely, we use the Micro Census waves 1991 (pre-placebo-treatment period) and 1996 (post-placebo-treatment period) and analyze whether treatment and control groups follow the same trends during that period.

According to our placebo treatment estimates, reported in Table 7, such reverse causality is not plausible. Using mothers whose youngest child is 10 or 11 as a control group, our placebo treatment estimates suggest marginally significant negative coefficients on the interaction term (After treatment $*$ Treatment group) (Columns 1 and 2). Adjusting for this slightly diverging trend in our main difference-in-differences specification would lead to even larger estimates than those presented in Table 7. This means that the results from Columns 1 and 2 of Table 6 should be interpreted as lower-bound estimates. In all other specifications using mothers without any children as our control group, we observe no placebo treatment effects, i.e., mothers with children aged three and four and women without children follow the same time trends in the years preceding the child care expansion (Columns 3-6).

\section{Table 7 about here}

In further regressions which are available from the authors upon request, we use the year 1993 instead of 1991 as the baseline year. In this specification, all placebo treatment estimates are insignificantly different from zero and precisely estimated at zero. Furthermore, we experimented with using mothers of three to four year olds from East Germany as an alternative control group. As can be seen from Figure A.1, child care attendance of three to four year old children in East Germany was flat and at a very high level during our period of observation, while child care attendance of three to four year old children in West Germany substantially increased from 1996 until 2001. Difference-in-differences regressions using this alternative control group yield results 
which are very similar to the ones from Table 6. However, the pre-treatment trends are rather different for these two groups. In particular, we observe a stark decline in East German employment (starting from a high level of more than 80 percent in 1991) during the first years after reunification, whereas the employment trend is rather flat in West Germany. This pretreatment trend difference does not allow us to make too rigorous conclusions from this exercise. Very similar arguments apply to another exercise where we used mothers of under three year olds from West Germany as an alternative control group. Note that child care attendance for under three year olds in West Germany is flat and at a very low level of under 10 percent during our period of observation. Difference-in-differences regressions using this control group again yield results which are very similar to those presented in Table 6 . However, also in this case, the pretreatment trends differ between treatment and control group. In particular, while the trends rather converge from 1993 until 1996, they diverge again in the late 1990s to reach a maximum employment gap in 2001. Therefore, we also do not over-interpret the results from this exercise.

Thus, taken together, our difference-in-differences estimates confirm the large and positive effects of public child care on maternal employment that we find in our instrumental variable approach. Indeed, estimates from the different empirical approaches are remarkably similar, although they do not necessarily measure the same effect. In particular, the IV setting identifies local average treatment effects (LATE) for the complier subpopulation whereas the difference-indifferences approach estimates average treatment effects on the treated (ATT). The reason for the fact that both approaches still yield very similar results could be that, in the end, in both identification strategies the same group of mothers is affected by the treatment, namely, those who have the opportunity to work because their three- or four-year-old child, who is also their youngest child, becomes eligible for public child care. ${ }^{20}$

\subsection{Cost-Benefit Analysis}

Since we have access to monthly gross and net wages in the SOEP data, we can perform some cautious back-of-the-envelope calculations that give at least some insight into the efficiency of public child care. In further IV regressions, which are available from the authors upon request, we find that public child care leads to an average increase in monthly earnings of 414.76 Euros

\footnotetext{
${ }^{20} \mathrm{~A}$ further concern could be the existence of general equilibrium effects: the expansion of public child care might indeed increase labor market participation of mothers with children aged three or four. At the same time, however, rising employment of those mothers could lead to a crowding out of mothers with older children or women without children. In such a case, public child care expansion might enhance labor market participation of mothers whose youngest child is aged three or four, but not women's employment as a whole. We are confident that this is only a minor issue given the small group of mothers whose youngest child is aged three or four who would-by this argument - have to crowd out the large group of mothers and women who are not affected by the public child care expansion.
} 
gross (235.75 Euros net). ${ }^{21}$ This corresponds to an average public income by means of income taxes and social security contributions per year of 2,148 Euros $(179 * 12)$ from the employee side. From the employer side, the public income via social security contributions corresponds to 1,030 Euros per year $(414.76 * 12 * 0.207) .{ }^{22}$ To provide some perspective on the efficiency of the child care subsidies, we draw on additional official statistics. According to Statistisches Bundesamt (2004), operating expenses per child care space net of parents' fees amounted to 2,988 Euros in 2002. In that year, 13 percent of all children in public child care were school children. If we assume, in accordance to Statistisches Bundesamt (2011), that the costs for public child care for school children are about a quarter of the costs for child care for children under the age of six, we compute operating expenses (net of parents' fees) per child care space for children under the age of six to be 3,324 Euros in 2002. Statistics from the German Micro Census suggest that if 1,000 kindergarten places are distributed randomly among all three- to six-year-old children, the distribution will include 648 families in which the three- to six-year-old child is indeed the family's youngest child. ${ }^{23}$ Accordingly, by providing 1,000 kindergarten places, the government generates income from income taxes and social security contributions of 2,060,000 Euros $\left((2.148+1.030)^{*} 648\right)$. These 1,000 kindergarten places cost the government 3,324,000 Euros $(3,324 * 1,000)$. Thus, more than 60 percent of the operating expenses of public child care (net of parents' fees) are covered by income taxes and social security contributions induced by the increase in maternal employment.

\section{Conclusions}

This paper provides evidence of large and positive causal effects of public child care on labor market participation of mothers in Germany, a country with traditionally low female, and in particular maternal employment rates. To establish causality, we exploit a policy reform from 1996 which introduced a legal claim to a place in kindergarten for all children from age three until school entry. Prior to the reform, public child care coverage for three and four year olds was far from universal in West Germany. At the same time, there was virtually no private market for child care. We rely on two identification strategies and two individual-level data sets. First, we use an instrumental variable approach that exploits age cut-off rules determining eligibility for public child care; these instrumental variable 2SLS estimations are based on rich individual-level data from the German Socio-Economic Panel (SOEP). Second, we apply difference-in-differences

\footnotetext{
${ }^{21}$ Incomes are measured in 2002 Euros. In these regressions, we dropped the top 3 percent in terms of income because these high income individuals constitute outliers that otherwise blur the analysis.

22The employer's social security contributions amount to 20.7 percent of an employee's gross earnings.

${ }^{23}$ This is the subsample for which our IV estimates are computed. We thereby implicitly assume that public child care for three- to six-year olds has zero effects on maternal employment if there is another child in the family who is younger than three.
} 
techniques exploiting the increase in public child care provision for three- and four-year-old children in Germany from 1996 to 2001 using data from the German Micro Census. Both identification strategies yield large and positive effects of public child care on maternal employment. A 10 percentage point increase in public child care provision increases employment of mothers whose youngest child is three to four years old by roughly 3.5 percentage points. On the other hand this means that roughly two thirds of these mothers use child care for other reasons than being employed. Some cautious attempts to evaluate the efficiency of the public child care subsidies suggest that more than 60 percent of the operating expenses of public child care (net of parents' fees) are covered by income taxes and social security contributions induced by the increase in maternal employment. Several robustness checks, including placebo treatment estimations, corroborate the validity of our empirical approaches.

In sum, our results show that expansion of public child care was a successful policy for increasing young mothers' labor market participation. Many studies on public child care effects and mothers' labor supply identify reduced form (intention-to-treat) effects; this makes it difficult to compare the size of the effects across these studies since the first stages might differ substantially. For our second-stage instrumental variable effects, however, we find that the size of our effects is very similar to the effects of the introduction of free kindergarten in U.S. public schools on the labor supply of single mothers whose youngest child is affected by the reform (Cascio 2009).

Note that we identify labor market effects only for mothers whose youngest child is at least three years old at the time of the interview. Recent family and child care policies are aimed at improving coverage for children younger than three, for whom public child care attendance is still much lower than it is for three- to six-year olds. Evidence as to the labor market effects of public child care for this age group is nearly nonexistent and thus clearly presents an opportunity for further research. Also, it would appear worthwhile to more rigorously extend the scope of research on public child care to discover its effects on fertility. A few recent papers begin to investigate this issue, but to date the empirical evidence on how public child care provision affects fertility is scarce and inconclusive. 


\section{Literature}

Angrist, Joshua D. and Alan B. Krueger. 1991. Does Compulsory Schools Attendance Affect Schooling and Earnings, Quarterly Journal of Economics, 106(4), 979-1014.

Baker, Michael, Gruber, Jonathan, and Kevin Milligan. 2008. Universal Child Care, Maternal Labor Supply, and Family Well-Being, Journal of Political Economy, 116(4), 709-745.

Bassok, Daphna, Fitzpatrick, Maria, and Susanna Loeb. 2012. Does State Preschool Crowd-Out Private Provision? The Impact of Universal Preschool on the Childcare Sector in Oklahoma and Georgia, NBER Working Paper, No.18605.

Berlinski, Samuel and Sebastian Galiani. 2007. The Effect of a Large Expansion of Pre-Primary School Facilities on Preschool Attendance and Maternal Employment, Labour Economics, 14, 665-680.

Berlinski, Samuel, Galiani, Sebastian, and Patrick J. McEwan. 2011. Preschool and Maternal Labour Market Outcomes: Evidence from a Regression Discontinuity Design, Economic Development and Cultural Change, 59(2), 313-344.

Bick, Alexander. 2011. The Quantitative Role of Child Care for Female Labor Force Participation and Fertility, Frankfurt, mimeo.

Blau, David M. 2003. Child Care Subsidy Programs, in: Robert Moffit (Hrsg.), Means Tested Social Programs, Chicago: University of Chicago Press.

Blau, David M. and Janet Currie. 2006. Preschool, Day Care, and After School Care: Who's Minding the Kids? in: E. A. Hanushek and F. Welch (Hrsg.), Handbook of the Economics of Education, 2, 1163-1278.

BMFSFJ. 2005. Zwoelfter Kinder- und Jugendbericht - Bericht über die Lebenssituation junger Menschen und die Leistungen der Kinder- und Jugendhilfe in Deutschland. Berlin: Bundestagsdrucksache 15/6014.

Buechel, Felix and C. Katharina Spiess. 2002. Kindertageseinrichtungen und Müttererwerbstätigkeit: Neue Erkenntnisse zu einem bekannten Zusammenhang, Vierteljahrshefte zur Wirtschaftsforschung, 71(1), 95-113.

Bundesgesetzblatt I. 2010. Sozialgesetzbuch: Achtes Buch - Kinder- und Jugendhilfe. 
Cascio, Elizabeth U. 2009. Maternal Labor Supply and the Introduction of Kindergartens into American Public Schools, Journal of Human Resources, 44(1), 140-170.

Coneus, Katja, Goeggel, Kathrin, and Grit Muehler. 2009. Maternal Employment and Child Care Decision, Oxford Economic Papers, 61, i172-i188.

Felfe, Christina and Rafael Lalive. 2012. Child Care and Child Development - What Works for Whom?, University of St. Gallen, mimeo.

Fitzpatrick, Maria Donovan. 2010. Preschoolers Enrolled and Mothers at Work? The Effects of Universal Pre-Kindergarten, Journal of Labor Economics, 28(1), 51-85.

Gathmann, Christina and Bjoern Sass. 2012. Taxing Childcare: Effects on Family Labor Supply and Children, IZA Discussion Paper No. 6440.

Gelbach, Jonah B. 2002. Public Schooling for Young Children and Maternal Labor Supply, American Economic Review, 92(1), 307-322.

Havnes, Tarjei and Magne Mogstad. 2011. Money for Nothing? Universal Child Care and Maternal Employment, Journal of Public Economics, 95(11-12), 1455-1465.

Konsortium Bildungsberichterstattung. 2006. Bildung in Deutschland. Ein indikatoren-gestützter Bericht mit einer Analyse zur Bildung und Migration. Bielefeld.

Lefebvre, Pierre and Philip Merrigan. 2008. Child-Care Policy and the Labor Supply of Mothers with Young Children: A Natural Experiment from Canada, Journal of Labor Economics, 26(3), $519-548$

Ludsteck, Johannes and Uta Schönberg. 2012. Expansions in Maternity Leave Coverage and Mothers' Labor Market Outcomes after Childbirth, Journal of Labor Economics, forthcoming.

Lundin, Daniela, Mörk, Eva, and Björn Öckert. 2008. How Far Can Reduced Childcare Prices Push Female Labour Supply? Labour Economics, 15(4), 647-659.

Nollenberger, Natalia and Núria Rodríguez-Planas. 2011. Child Care, Maternal Employment and Persistence: A Natural Experiment from Spain, IZA Discussion Paper No. 5888.

Rauschenbach, Thomas. 2006. Wer betreut Deutschlands Kinder - Eine einleitende Skizze, in: W. Bien, T. Rauschenbach and B. Riedel (eds.), Wer betreut Deutschlands Kinder? BeltzVerlag, Weinheim und Basel, 10-24. 
Rubin, Donald. 1978. Bayesian Inference for Causal Effects: The Role of Randomization, Annals of Statistics, 6, 34-58.

Schlosser, Analia. 2007. Public Preschool and the Labor Supply of Arab Mothers: Evidence from a Natural Experiment, University of Jerusalem, mimeo.

Schlotter, Martin. 2011. Age at Preschool Entrance and Noncognitive Skills before School - An Instrumental Variable Approach, Ifo Working Paper No. 112.

Spieß, Katharina, 1998. Staatliche Eingriffe in Märkte für Kinderbetreuung. Analysen im deutschamerikanischen Vergleich, Frankfurt a.M. \& New York: Campus Verlag.

Statistisches Bundesamt. 2004. Kindertagesbetreunng in Deutschland: Einrichtungen, Plätze, Personal und Kosten 1990 bis 2002, Wiesbaden: Statistisches Bundesamt.

Statistisches Bundesamt. 2011. Statistiken der Kinder-und Jugendhilfe: Ausgaben und Einnahmen 2009, Wiesbaden: Statistisches Bundesamt.

Tietze, Wolfgang and Hans-Günther Rossbach. 1991. Die Betreuung von Kindern im vorschulischen Alter, Zeitschrift für Pädagogik, 37(4), 555-602. 


\section{Appendix}

Figure A.1: Kindergarten attendance in East Germany

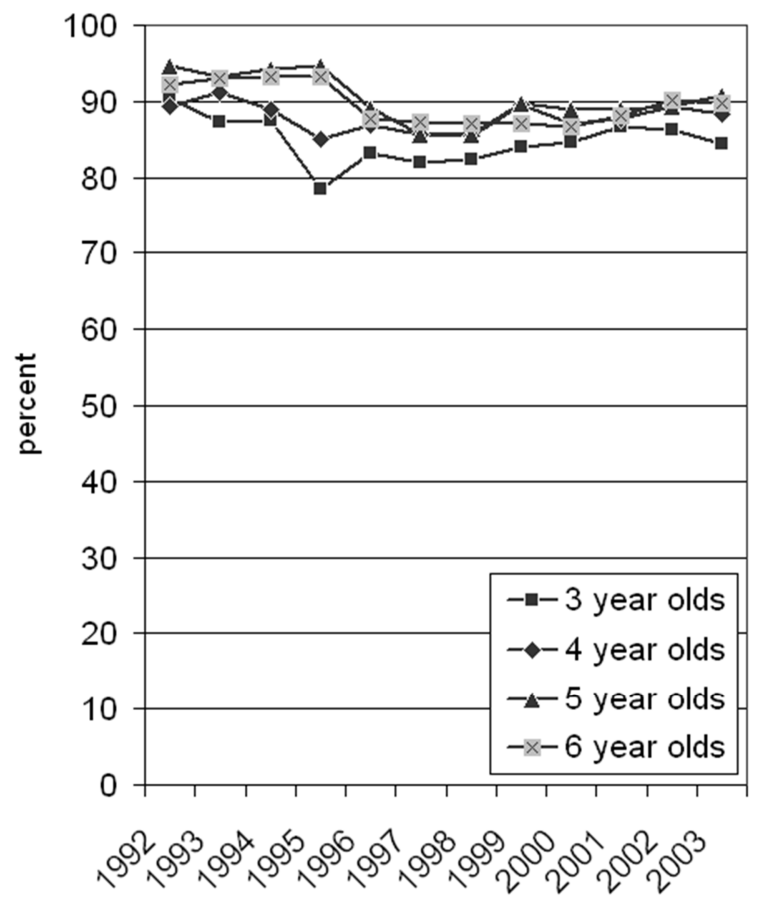

Notes: The figure shows the percentage of all children of the respective age who attend child care in East Germany. Data: Micro Census. Source: BMFSFJ (2005, p.299). 
Table A.1: Descriptive statistics for the treatment and the control groups in 1996 and 2001

\begin{tabular}{|c|c|c|c|c|}
\hline & \multicolumn{2}{|c|}{1996} & \multicolumn{2}{|c|}{2001} \\
\hline & Mean & $\mathrm{SD}$ & Mean & $\mathrm{SD}$ \\
\hline \multicolumn{5}{|l|}{ Treatment Group (mother's youngest child is 3 or 4): } \\
\hline Employment $(1=$ yes, $0=$ no $)$ & 0.467 & & 0.578 & \\
\hline Mother's age & 33.00 & 6.00 & 34.02 & 5.57 \\
\hline \multicolumn{5}{|l|}{ Mother's highest school degree: } \\
\hline General school & 0.404 & & 0.343 & \\
\hline Intermediate school & 0.303 & & 0.336 & \\
\hline Upper secondary technical school degree & 0.035 & & 0.047 & \\
\hline School degree from East Germany & 0.023 & & 0.014 & \\
\hline High school & 0.154 & & 0.193 & \\
\hline School degree missing & 0.082 & & 0.068 & \\
\hline Nationality $($ German $=1$, non-German or two nationalities $=0)$ & 0.863 & & 0.855 & \\
\hline Distance to oldest sibling (in years) & 3.37 & 4.08 & 3.56 & 4.08 \\
\hline Single mother $(1=$ yes, $0=$ no $)$ & 0.095 & & 0.111 & \\
\hline $\mathrm{N}$ & 5,853 & & 5,573 & \\
\hline \multicolumn{5}{|l|}{ Control Group (mother's youngest child is 10 or 11): } \\
\hline Employment $(1=$ yes, $0=$ no $)$ & 0.651 & & 0.71 & \\
\hline Mother's age & 39.7 & 5.4 & 40.32 & 5.30 \\
\hline \multicolumn{5}{|l|}{ Mother's highest school degree: } \\
\hline General school & 0.467 & & 0.417 & \\
\hline Intermediate school & 0.269 & & 0.314 & \\
\hline Upper secondary technical school degree & 0.032 & & 0.041 & \\
\hline School degree from East Germany & 0.025 & & 0.013 & \\
\hline High school & 0.132 & & 0.149 & \\
\hline School degree missing & 0.076 & & 0.067 & \\
\hline Nationality $($ German $=1$, non-German or two nationalities $=0)$ & 0.896 & & 0.896 & \\
\hline Distance to oldest sibling (in years) & 3.34 & 3.52 & 3.3 & 3.56 \\
\hline Single mother $(1=$ yes, $0=$ no $)$ & 0.149 & & 0.127 & \\
\hline $\mathrm{N}$ & 4,020 & & 4,540 & \\
\hline \multicolumn{5}{|l|}{ Control Group (women w/ o children aged $>29 \Leftrightarrow<<=36$ ): } \\
\hline Employment $(1=$ yes, $0=$ no $)$ & 0.875 & & 0.903 & \\
\hline Woman's age & 32.57 & 1.99 & 32.77 & 2.00 \\
\hline \multicolumn{5}{|l|}{ Woman's highest school degree: } \\
\hline General school & 0.232 & & 0.186 & \\
\hline Intermediate school & 0.297 & & 0.326 & \\
\hline Upper secondary technical school degree & 0.067 & & 0.073 & \\
\hline School degree from East Germany & 0.021 & & 0.014 & \\
\hline High school & 0.316 & & 0.359 & \\
\hline School degree missing & 0.069 & & 0.042 & \\
\hline Nationality $($ German $=1$, non-German or two nationalities $=0)$ & 0.937 & & 0.926 & \\
\hline $\mathrm{N}$ & 7,002 & & 7,472 & \\
\hline
\end{tabular}


Control Group (women w/ o children aged >=18 $\diamond<60$ ):

\begin{tabular}{lrrr} 
Employment $(1=$ yes, $0=$ no $)$ & 0.693 & 0.737 & 12.5 \\
Woman's age & 41.51 & 12.78 & 41.54 \\
Woman's highest school degree: & & 0.381 \\
& General school & 0.438 & 0.265 \\
& Intermediate school & 0.243 & 0.05 \\
& Upper secondary technical school degree & 0.037 & 0.011 \\
School degree from East Germany & 0.019 & 0.228 \\
Nationality (German=1, non-German or two nationalities=0) High school & 0.184 & 0.070 \\
$\mathrm{~N}$ & School degree missing & 0.079 & 0.922 \\
\hline
\end{tabular}


Table A.2: Reduced-form and 2SLS estimates on sample with single mothers and mothers with partners (without partner covariates)

Employment yes/no

Weekly working hours

\begin{tabular}{|c|c|c|c|c|c|c|c|}
\hline & \multicolumn{3}{|c|}{ 2SLS } & & \multirow[b]{2}{*}{$\begin{array}{l}\text { Reduced form } \\
\text { (1) } \\
\end{array}$} & \multicolumn{2}{|c|}{ 2SLS } \\
\hline & $\begin{array}{c}\text { Reduced form } \\
\text { (1) }\end{array}$ & $\begin{array}{c}\text { First stage } \\
(2) \\
\end{array}$ & $\begin{array}{c}\text { Second stage } \\
\text { (3) }\end{array}$ & & & $\begin{array}{c}\text { First stage } \\
(2)\end{array}$ & $\begin{array}{c}\text { Second stage } \\
\text { (3) }\end{array}$ \\
\hline Above cut-off age at last kindergarten start & $\begin{array}{l}0.060^{*} \\
(0.033)\end{array}$ & & $\begin{array}{l}0.345^{*} \\
(0.189)\end{array}$ & Above cut-off age at last kindergarten start & $\begin{array}{c}2.129 * * \\
(1.002)\end{array}$ & & $\begin{array}{c}12.572^{* *} \\
(5.917)\end{array}$ \\
\hline Child care & & $\begin{array}{c}0.175^{* * *} \\
(0.028)\end{array}$ & & Child care & & $\begin{array}{c}0.169^{* * *} \\
(0.028)\end{array}$ & \\
\hline Year controls & Yes & Yes & Yes & Year controls & Yes & Yes & Yes \\
\hline Federal state controls & Yes & Yes & Yes & Federal state controls & Yes & Yes & Yes \\
\hline Individual-level controls & Yes & Yes & Yes & Individual-level controls & Yes & Yes & Yes \\
\hline First-stage F-test & & & & First-stage F-test & & & \\
\hline $\begin{array}{r}\text { Robust F statistic } \\
\end{array}$ & & & 400 & $\begin{array}{r}\text { Robust F statistic } \\
\end{array}$ & & & 875 \\
\hline Prob $>$ F & 2,286 & & 86 & Prob $>\mathrm{F}$ & 2,245 & & 45 \\
\hline $\mathrm{R}^{2}$ & 0.099 & & 13 & $\mathrm{R}^{2}$ & 0.147 & & 39 \\
\hline
\end{tabular}


Table A.3: Reduced-form and 2SLS estimates on sample of mothers whose youngest child is close to the cut-off

Employment (yes/no)

$\frac{\text { Employment (yes } / \text { mo) }}{2 \mathrm{SLS}}$

Sample: Youngest child's age at kindergarten start...

30-42 months

32-40 months

First stage Second stage

(II)

First stage

(II)

Second stage

(III)

$0.122 * * *$

Above cut-off age at last kindergarten start

$0.127^{* * *}$

(0.036)

Child care

0.36

(0.038)

0.363

(0.324)

Year controls

Yes

Yes

Yes

Yes

Yes

Yes
Yes
Yes

Individual level controls

Yes

\section{Robust F statistic \\ Prob $>$ F}

12.833

0.000

1,221

0.131

(11)

$\mathrm{R}^{2}$

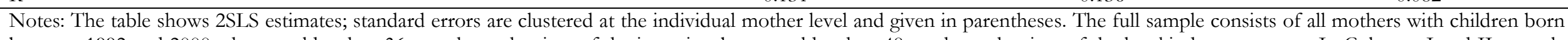

Yes

\begin{tabular}{cc} 
& 0.310 \\
& $(0.348)$ \\
Yes & Yes \\
Yes & Yes \\
Yes & Yes \\
\hline
\end{tabular}

$\begin{array}{cc}10.646 & 9.275 \\ 0.001 & 0.003 \\ 917 & 541 \\ 0.136 & 0.082\end{array}$

2SLS

34-38 months

Second stage

(V)

$0.125^{* * *}$

(0.041)

(VI)

0.460

$(0.388)$

Yes

Yes

Yes between 1992 and 2000 who are older than 36 months at the time of the interview but not older than 48 moths at the time of the last kindergarten start. In Columns I and II we only

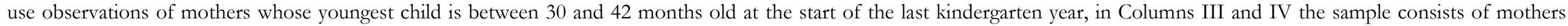

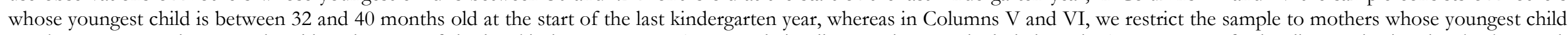
was between 34 and 38 months old at the start of the last kindergarten year. As controls in all regressions are included mother's age, years of schooling, and migration background;

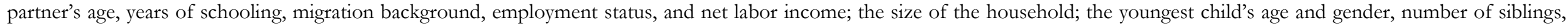
and distance (in months) to his or her oldest sibling; as well as state and year dummies.

*** $1 \%$ level of significance, $* * 5 \%$ level of significance, $* 10 \%$ level of significance. Data: SOEP. 
Table A.4: Difference-in-differences estimation using various control groups and multiple post-treatment periods

\begin{tabular}{|c|c|c|c|c|c|c|}
\hline \multirow{3}{*}{ Control group: Women with... } & \multicolumn{6}{|c|}{ EMPLOYED (yes=1, no=0) } \\
\hline & \multicolumn{2}{|c|}{ 10-11-year-old kids } & \multicolumn{2}{|c|}{ No kids (age 29-36) } & \multicolumn{2}{|c|}{ No kids (age 18-60) } \\
\hline & (1) & $(2)$ & (3) & (4) & (5) & $(6)$ \\
\hline \multirow[t]{2}{*}{ Treatment group (yes $=1$, no $=0$ ) } & $-0.183^{* * *}$ & $-0.202 * * *$ & $-0.407 * * *$ & $-0.369 * * *$ & $-0.226 * * *$ & $-0.285^{* * *}$ \\
\hline & $(0.010)$ & $(0.010)$ & $(0.007)$ & $(0.007)$ & $(0.006)$ & $(0.006)$ \\
\hline \multirow[t]{2}{*}{ After treatment $(1997=1,1996=0)$} & 0.000 & -0.004 & -0.010 & -0.011 & 0.000 & 0.001 \\
\hline & $(0.011)$ & $(0.011)$ & $(0.007)$ & $(0.007)$ & $(0.003)$ & $(0.003)$ \\
\hline \multirow[t]{2}{*}{ After treatment $(1998=1,1996=0)$} & 0.013 & 0.009 & 0.007 & 0.004 & 0.004 & $0.008^{* * *}$ \\
\hline & $(0.011)$ & $(0.010)$ & $(0.007)$ & $(0.007)$ & $(0.003)$ & $(0.003)$ \\
\hline \multirow[t]{2}{*}{ After treatment $(1999=1,1996=0)$} & $0.023^{* *}$ & $0.017^{*}$ & 0.011 & 0.003 & $0.022 * * *$ & $0.022 * * *$ \\
\hline & $(0.011)$ & $(0.010)$ & $(0.007)$ & $(0.007)$ & $(0.003)$ & $(0.003)$ \\
\hline \multirow[t]{2}{*}{ After treatment $(2000=1,1996=0)$} & $0.045^{* * *}$ & $0.042^{* * *}$ & $0.020^{* * *}$ & $0.015^{* *}$ & $0.031 * * *$ & $0.033^{* * *}$ \\
\hline & $(0.011)$ & $(0.010)$ & $(0.007)$ & $(0.007)$ & $(0.003)$ & $(0.003)$ \\
\hline \multirow[t]{2}{*}{ After treatment $(2001=1,1996=0)$} & $0.059 * * *$ & $0.052^{* * *}$ & $0.028^{* * *}$ & $0.021 * * *$ & $0.044 * * *$ & $0.041 * * *$ \\
\hline & $(0.011)$ & $(0.010)$ & $(0.007)$ & $(0.007)$ & $(0.003)$ & $(0.003)$ \\
\hline \multirow[t]{2}{*}{ After treatment $*$ Treatment group (after period 1997) } & 0.022 & $0.023^{*}$ & $0.032^{* * *}$ & $0.034 * * *$ & $0.022^{* *}$ & $0.024^{* *}$ \\
\hline & $(0.014)$ & $(0.014)$ & $(0.010)$ & $(0.010)$ & $(0.009)$ & $(0.009)$ \\
\hline \multirow[t]{2}{*}{ After treatment $*$ Treatment group (after period 1998) } & 0.007 & 0.010 & 0.013 & 0.016 & $0.015^{*}$ & 0.014 \\
\hline & $(0.014)$ & $(0.014)$ & $(0.010)$ & $(0.010)$ & $(0.009)$ & $(0.009)$ \\
\hline \multirow[t]{2}{*}{ After treatment $*$ Treatment group (after period 1999) } & $0.032^{* *}$ & $0.037 * * *$ & $0.045^{* * *}$ & $0.051 * * *$ & $0.033^{* * *}$ & $0.037 * * *$ \\
\hline & $(0.014)$ & $(0.014)$ & $(0.010)$ & $(0.010)$ & $(0.009)$ & $(0.009)$ \\
\hline \multirow[t]{2}{*}{ After treatment $*$ Treatment group (after period 2000) } & $0.037 * * *$ & $0.037 * * *$ & $0.062^{* * *}$ & $0.065^{* * *}$ & $0.051 * * *$ & $0.054 * * *$ \\
\hline & $(0.014)$ & $(0.014)$ & $(0.010)$ & $(0.010)$ & $(0.009)$ & $(0.009)$ \\
\hline \multirow[t]{2}{*}{ After treatment $*$ Treatment group (after period 2001) } & $0.052^{* * *}$ & $0.052 * * *$ & $0.083^{* * *}$ & $0.083^{* * *}$ & $0.067 * * *$ & $0.071 * * *$ \\
\hline & $(0.014)$ & $(0.014)$ & $(0.010)$ & $(0.010)$ & $(0.009)$ & $(0.009)$ \\
\hline Individual control variables & No & Yes & No & Yes & No & Yes \\
\hline $\mathrm{N}$ & 58,910 & 58,910 & 76,924 & 74,605 & 325,173 & 303,612 \\
\hline $\mathrm{R}^{2}$ & 0.03 & 0.07 & 0.17 & 0.21 & 0.02 & 0.10 \\
\hline
\end{tabular}

Notes: The table shows difference-in-differences estimates; robust standard errors in parentheses. As controls in Column 2 are included mother's age, mother's highest school degree, nationality, a dummy for single mothers, and the age distance of the youngest children to their oldest siblings. In Columns 4 and 6 we included women's age, women's highest school degree, and nationality as control variables. ${ }^{* *} 1 \%$ level of significance, ${ }^{* *} 5 \%$ level of significance, $* 10 \%$ level of significance. Data: Micro Census. 
Table A.5: Difference-in-differences estimation for mothers with partners and single mothers

Control group: Women with...

EMPLOYED $($ Yes $=1$, no $=0)$

10-11-year-old kids

Mothers with Partners

(1)

Treatment group (yes $=1$, no $=0$ )

$-0.171 * * *$

(2)

Single Mothers

(0.011)

After treatment $(2001=1,1996=0)$

$0.061 * * *$

After treatment*'Treatment group

(0.011)

$-0.198^{* * *}$

(3)

(4)

Individual control variables

$0.050^{* * *}$

(0.011)

$-0.263^{* * *}$

$-0.232^{* * *}$

$\mathrm{N}$

(0.015)

$0.055^{* * *}$

$(0.011)$

$0.051 * * *$

No

$(0.015)$

Yes

\begin{tabular}{lr}
$\mathrm{R}^{2}$ & 0.03 \\
\hline Notes: The table shows difference-in-differences estimates; robust standard errors in pare
\end{tabular}

17,623

0.07

(0.028)

(0.030)

0.029

0.034

$(0.027)$

$0.079 * *$

$0.070^{*}$

$(0.037)$

No degree, nationality, a dummy for single mothers, and the age distance of the youngest children to their oldest siblings.*** $1 \%$ level of significance, $* * 5 \%$ level of significance, $* 10 \%$ level of significance. Data: Micro Census. 


\section{Figures}

Figure 1: Kindergarten attendance in West Germany

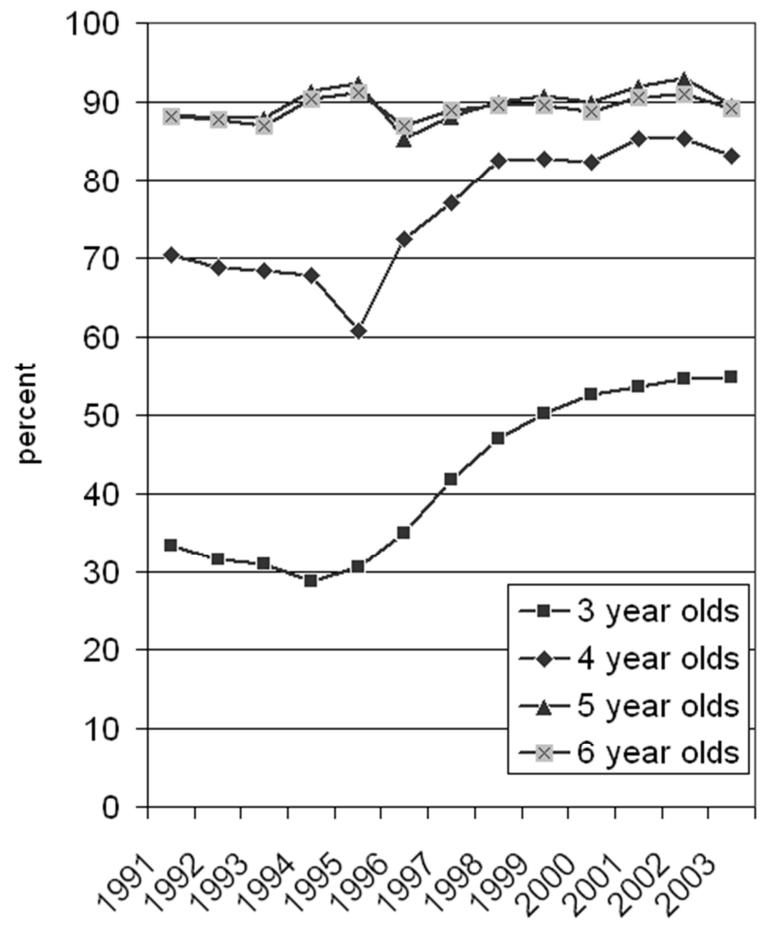

Notes: The figure shows the percentage of all children of the respective age who attend child care in West Germany. Data: Micro Census. Source: BMFSFJ (2005, p. 299). 
Figure 2: Kindergarten entry months
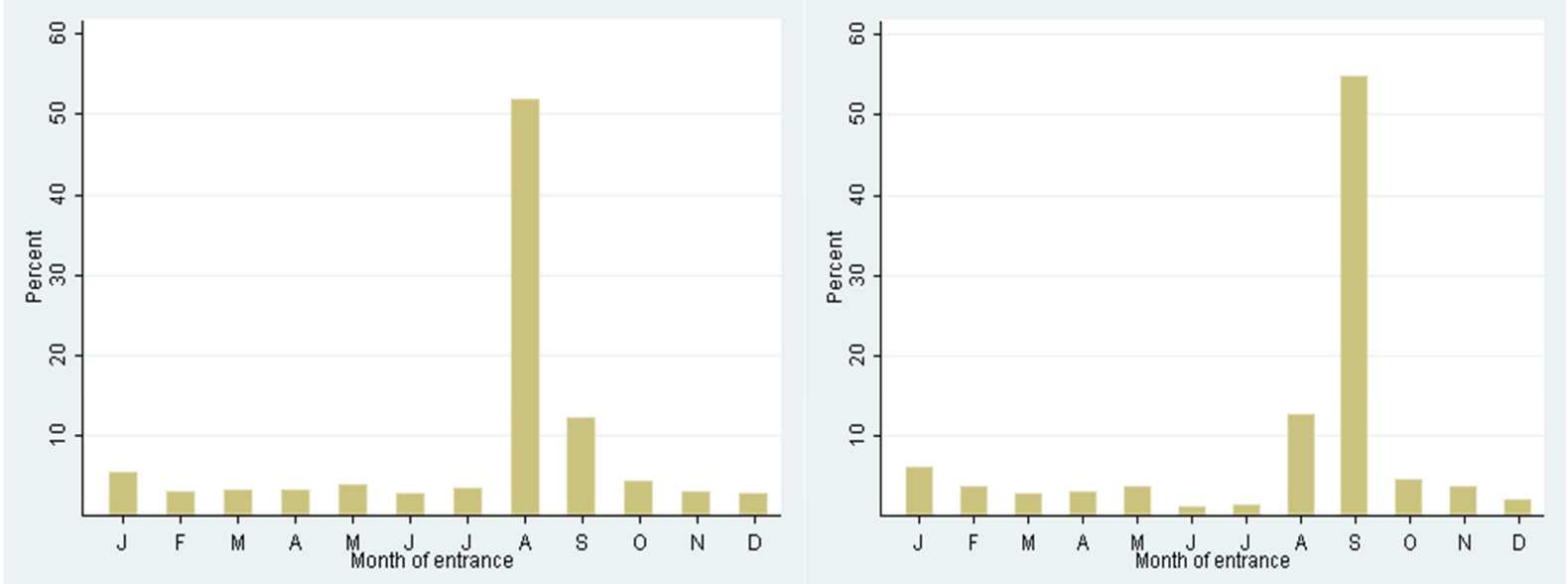

Notes: The left figure shows the percentage of all kindergarten children who entered kindergarten in the respective month for federal state-year combinations where kindergarten start was in August; the right figure shows the respective percentages for federal state-year combinations where kindergarten start was in September. Data: DJI Kinderpanel. 
Figure 3: The age-cut off rule and a child's kindergarten attendance

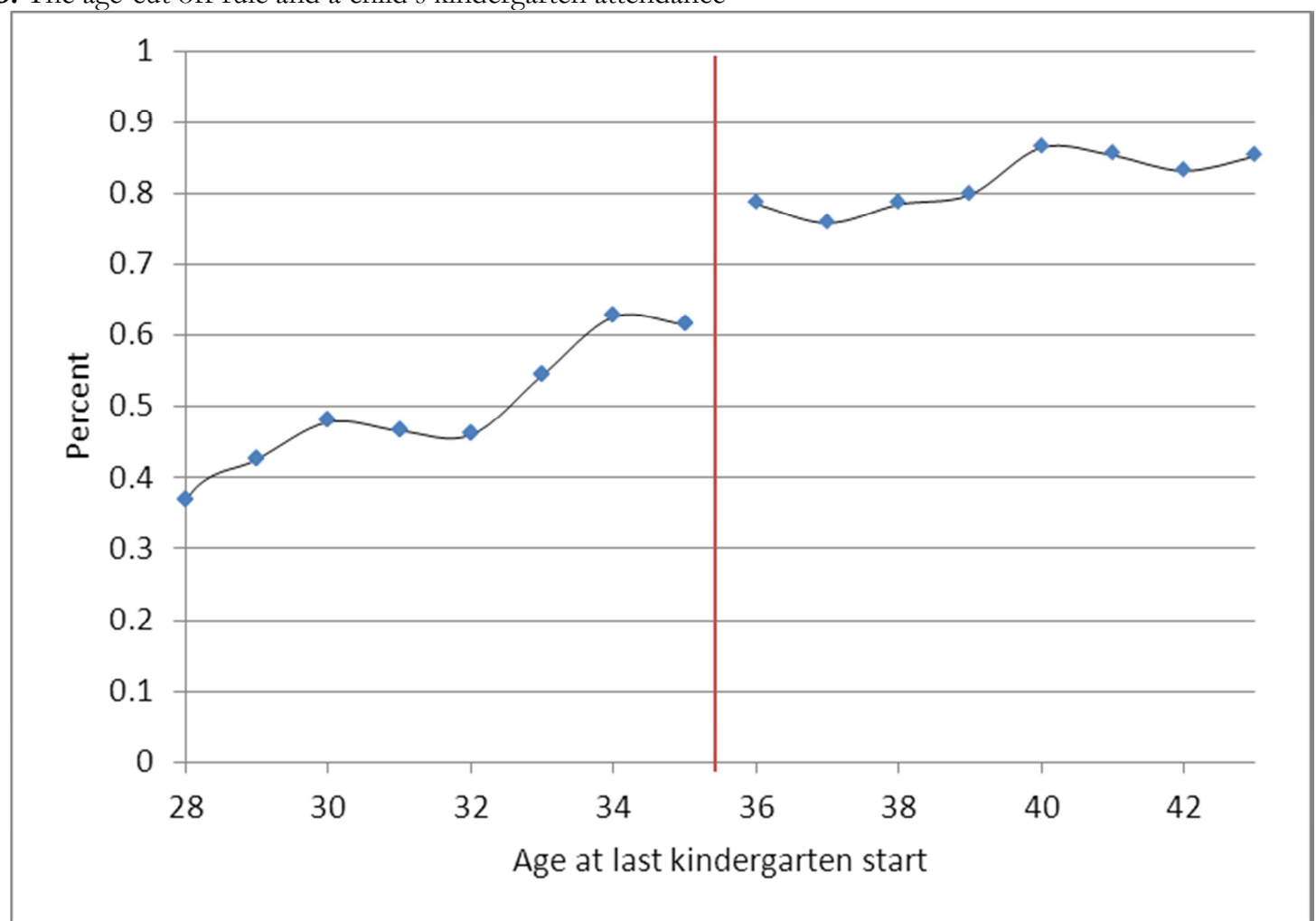

Notes: The figure shows kindergarten attendance rates by age (in moths) at last kindergarten start. Kindergarten attendance is measured roughly half a year after the last kindergarten start. The sample consists of all mothers with children born between 1992 to 2000 who are older than 36 months at the time of the interview but not older than 48 moths at the time of the last kindergarten start. Data: SOEP. 
Figure 4: The age-cut off rule and a mother's employment rate

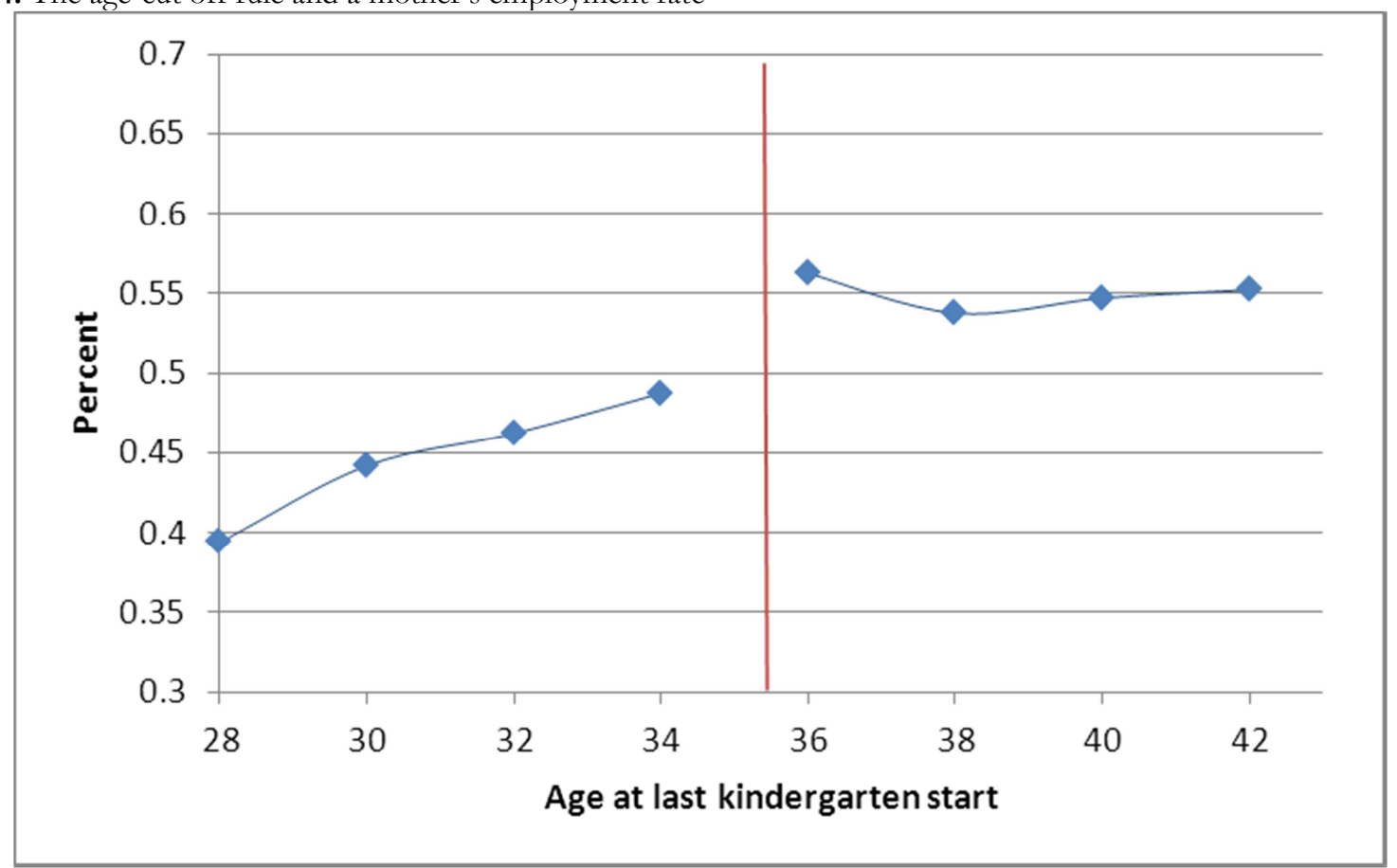

Notes: The figure shows maternal employment rates by her youngest dhild's age (in moths) at last kindergarten start. Employment is measured roughly half a year after the last kindergarten start. The sample consists of all mothers with children born between 1992 to 2000 who are older than 36 months at the time of the interview but not older than 48 moths at the time of the last kindergarten start. Data: SOEP. 
Figure 5: Employment over time for different groups of women in West Germany

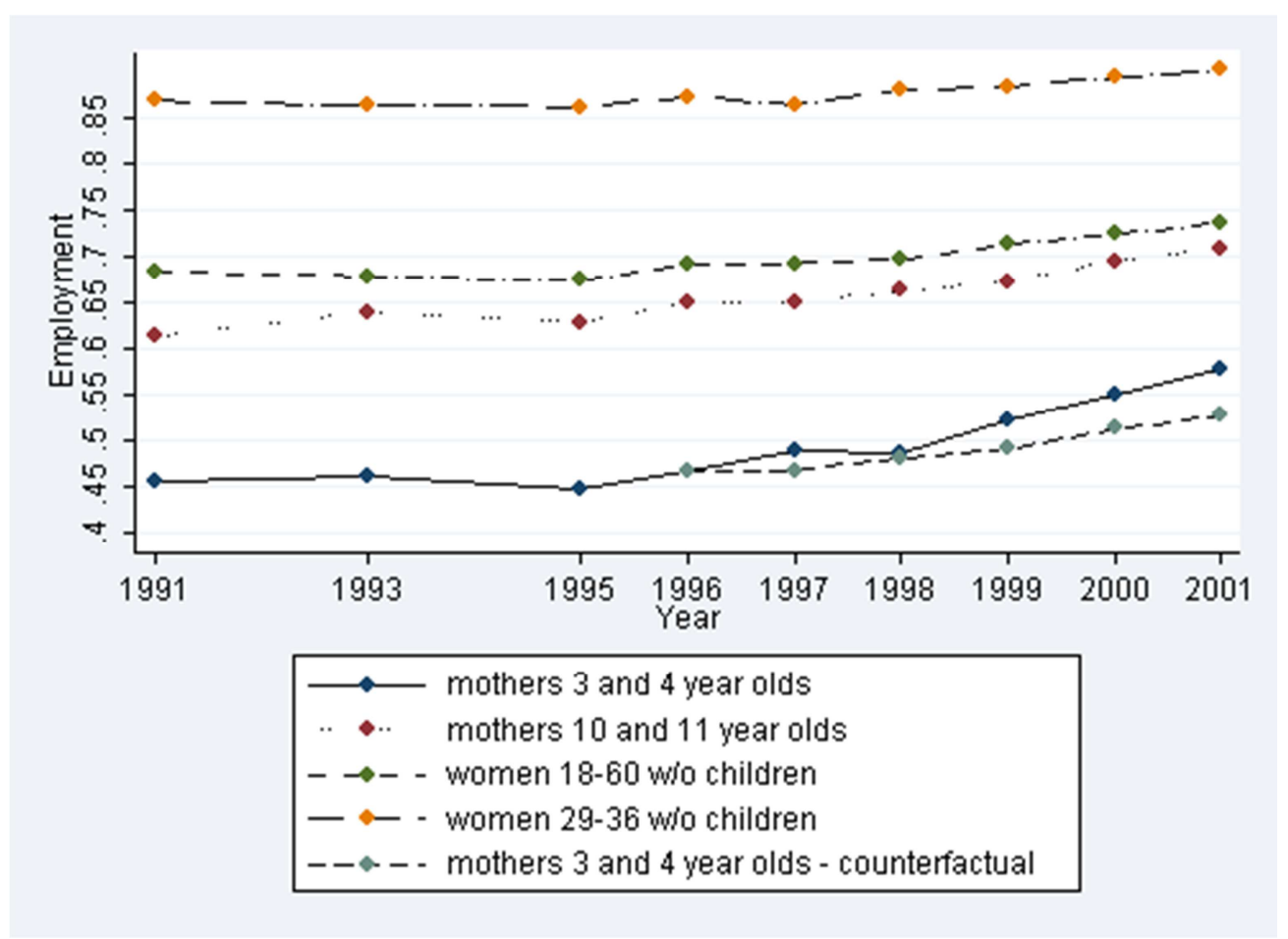

Notes: The figure shows the development of employment for various groups of women in West Germany for the years 1991 to 2001. Data: Micro Census. 


\section{Tables}

Table 1: Descriptive statistics on control variables

\begin{tabular}{|c|c|c|c|}
\hline & \multicolumn{2}{|c|}{ Age at last kindergarten start } & \multirow{2}{*}{$\begin{array}{c}\text { Difference } \\
\text { t value }\end{array}$} \\
\hline & $<36$ months & $>=36$ months & \\
\hline \multirow[t]{2}{*}{ Mother's years of schooling } & 11.842 & 11.838 & 0.035 \\
\hline & $(0.095)$ & $(0.068)$ & \\
\hline \multirow[t]{2}{*}{ Mother's migration background } & 0.268 & 0.274 & 0.293 \\
\hline & $(0.017)$ & $(0.012)$ & \\
\hline \multirow[t]{2}{*}{ Partner's years of schooling } & 12.115 & 12.149 & 0.258 \\
\hline & $(0.105)$ & $(0.075)$ & \\
\hline \multirow[t]{2}{*}{ Partner's migration background } & 0.285 & 0.283 & 0.068 \\
\hline & $(0.018)$ & $(0.012)$ & \\
\hline \multirow[t]{2}{*}{ Partner's employment } & 0.919 & 0.914 & 0.397 \\
\hline & $(0.011)$ & $(0.008)$ & \\
\hline \multirow[t]{2}{*}{ Partner's net labor income (in $€$ ) } & $1,871.77$ & $1,881.82$ & 0.171 \\
\hline & $(48.17)$ & $(33.73)$ & \\
\hline \multirow[t]{2}{*}{ Child's gender (female) } & 0.511 & 0.511 & 0.013 \\
\hline & $(0.020)$ & $(0.014)$ & \\
\hline \multirow[t]{2}{*}{ Child's distance to oldest sibling (in months) } & 39.988 & 40.475 & 0.356 \\
\hline & $(1.630)$ & $(1.088)$ & \\
\hline \multirow[t]{2}{*}{ Child's number of siblings } & 0.880 & 0.929 & 1.216 \\
\hline & $(0.032)$ & $(0.023)$ & \\
\hline \multirow[t]{2}{*}{ Number of household members } & 3.992 & 4.083 & 1.847 \\
\hline & $(0.038)$ & $(0.029)$ & \\
\hline \multicolumn{4}{|l|}{ Age variables } \\
\hline \multirow[t]{2}{*}{ Mother's age (in years) } & 32.942 & 34.037 & 4.690 \\
\hline & $(0.185)$ & $(0.136)$ & \\
\hline \multirow[t]{2}{*}{ Partner's age (in years) } & 35.588 & 36.683 & 4.203 \\
\hline & $(0.208)$ & $(0.151)$ & \\
\hline \multirow[t]{2}{*}{ Child's age (in months) } & 39.075 & 48.239 & 50.182 \\
\hline & $(0.089)$ & $(0.120)$ & \\
\hline
\end{tabular}

Notes: The sample consists of all mothers with children born between 1992 to 2000 who are older than 36 months at the time of the interview but not older than 48 moths at the time of the last kindergarten start. The table shows means; standard deviations are given in parentheses. Data: SOEP. 
Table 2: First-stage estimates

\begin{tabular}{|c|c|c|c|c|c|c|c|}
\hline & \multirow[b]{2}{*}{$\begin{array}{c}\text { Full sample } \\
\text { (I) } \\
\end{array}$} & \multicolumn{6}{|c|}{ KINDERGARTEN ATTENDANCE AT INTERVIEW } \\
\hline & & $\begin{array}{c}\text { Full sample } \\
\text { (II) } \\
\end{array}$ & $\begin{array}{l}\text { West } \\
\text { (III) } \\
\end{array}$ & $\begin{array}{l}\text { East } \\
(\mathrm{IV}) \\
\end{array}$ & $\begin{array}{c}\text { Year }<2000 \\
(\mathrm{~V}) \\
\end{array}$ & $\begin{array}{c}\text { Year }>=2000 \\
(\mathrm{VI})\end{array}$ & $\begin{array}{c}1991-1995 \\
(\mathrm{VII}) \\
\end{array}$ \\
\hline Above cut-off age at last kindergarten start & $\begin{array}{c}0.178^{* * *} \\
(0.032)\end{array}$ & $\begin{array}{c}0.176 * * * \\
(0.030)\end{array}$ & $\begin{array}{c}0.195^{* * *} \\
(0.034)\end{array}$ & $\begin{array}{c}0.077 \\
(0.056)\end{array}$ & $\begin{array}{c}0.233^{* * *} \\
(0.059)\end{array}$ & $\begin{array}{c}0.158^{* * *} \\
(0.036)\end{array}$ & $\begin{array}{c}0.020 \\
(0.049)\end{array}$ \\
\hline Year controls & No & Yes & Yes & Yes & Yes & Yes & Yes \\
\hline Federal state controls & No & Yes & Yes & Yes & Yes & Yes & Yes \\
\hline Individual level controls & No & Yes & Yes & Yes & Yes & Yes & Yes \\
\hline $\mathrm{N}$ & 1,936 & 1,936 & 1,617 & 319 & 589 & 1,347 & 943 \\
\hline $\mathrm{R}^{2}$ & 0.148 & 0.285 & 0.301 & 0.220 & 0.343 & 0.248 & 0.317 \\
\hline
\end{tabular}

Notes: The table shows first-stage estimates; standard errors are clustered at the individual mother level and given in parentheses. The sample for Columns (I) through (VI) consists of

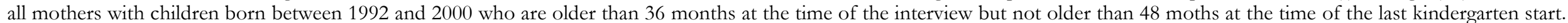

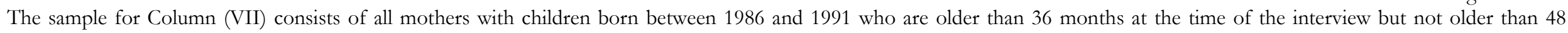
months at the time of the last kindergarten start. In column (I), we only control for the youngest child's age (in month). As controls in columns (II) through (VII) are included mother's

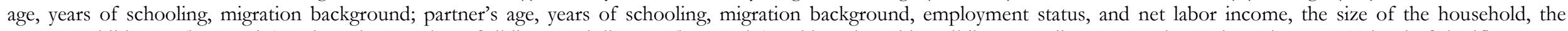

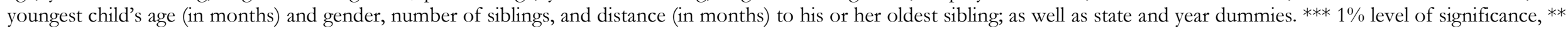
$5 \%$ level of significance, $* 10 \%$ level of significance. Data: SOEP. 
Table 3: Reduced-form and 2SLS estimates on employment

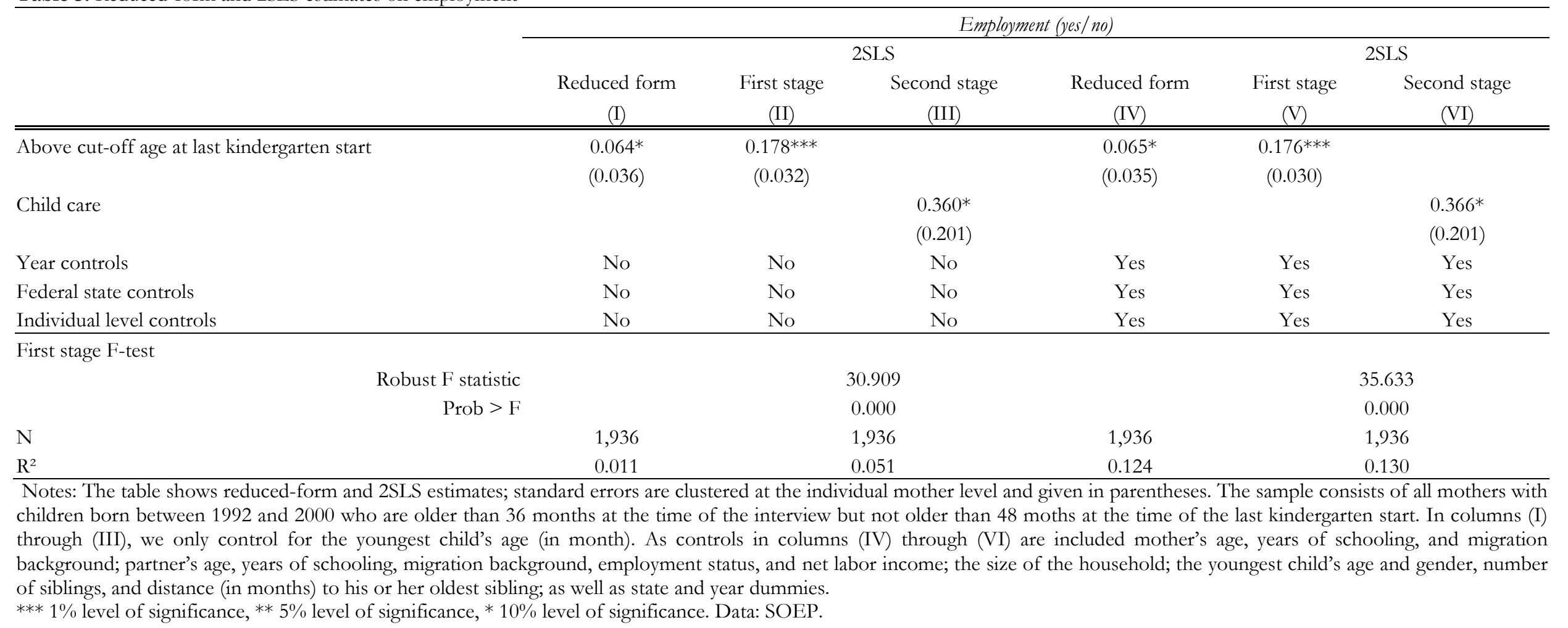


Table 4: Reduced-form and 2SLS estimates on weekly working hours

Weekly working hours

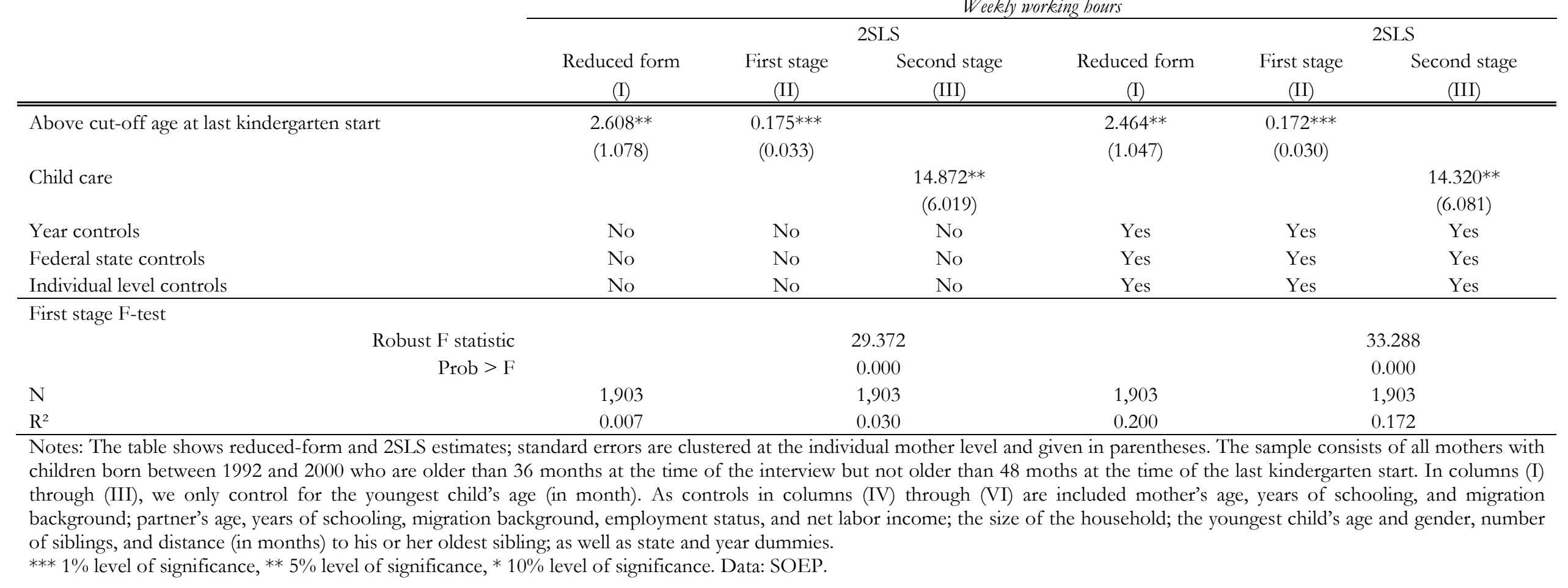


Table 5: Reduced-form and 2SLS estimates: Placebo treatment test

\begin{tabular}{|c|c|c|c|c|c|c|}
\hline & \multicolumn{3}{|c|}{ Employment yes/no (t-1) } & \multicolumn{3}{|c|}{ Weekly working hours (t-1) } \\
\hline & \multicolumn{3}{|c|}{ 2SLS } & \multirow{2}{*}{$\begin{array}{l}\text { Reduced form } \\
\text { (4) }\end{array}$} & \multicolumn{2}{|c|}{ 2SLS } \\
\hline & $\begin{array}{l}\text { Reduced form } \\
\text { (1) }\end{array}$ & $\begin{array}{l}\text { First stage } \\
\text { (2) }\end{array}$ & $\begin{array}{l}\text { Second stage } \\
\text { (3) }\end{array}$ & & $\begin{array}{l}\text { First stage } \\
\text { (5) }\end{array}$ & $\begin{array}{l}\text { Second stage } \\
(6)\end{array}$ \\
\hline \multirow[t]{2}{*}{$\begin{array}{l}\text { Above cut-off age at } \\
\text { last kindergarten start }\end{array}$} & 0.011 & $0.183^{* * *}$ & & -0.308 & $0.175^{* * *}$ & \\
\hline & $(0.035)$ & $(0.030)$ & & $(0.976)$ & $(0.030)$ & \\
\hline Child care & & & $\begin{array}{c}0.060 \\
(0.188)\end{array}$ & & & $\begin{array}{l}-1.754 \\
(5.535)\end{array}$ \\
\hline Year controls & Yes & Yes & Yes & Yes & Yes & Yes \\
\hline Federal state controls & Yes & Yes & Yes & Yes & Yes & Yes \\
\hline Individual-level controls & Yes & Yes & Yes & Yes & Yes & Yes \\
\hline \multicolumn{7}{|l|}{ First-stage F-test } \\
\hline Robust F statistic & \multicolumn{3}{|c|}{37.661} & & \multicolumn{2}{|c|}{34.227} \\
\hline Prob $>$ F & \multicolumn{3}{|c|}{0.000} & & \multicolumn{2}{|c|}{0.000} \\
\hline $\mathrm{N}$ & 1,911 & \multicolumn{2}{|c|}{1,911} & 1,887 & \multicolumn{2}{|c|}{1,887} \\
\hline $\mathrm{R}^{2}$ & 0.125 & \multicolumn{2}{|c|}{0.133} & 0.215 & \multicolumn{2}{|c|}{0.206} \\
\hline
\end{tabular}


Table 6: Difference-in-differences estimations using various control groups

\begin{tabular}{lcccccc}
\hline & \multicolumn{7}{c}{ EMPLOYED (yes=1, no=0) } \\
Control group: Women with... & $10-11$-year-old kids & No kids (age 29-36) & No kids (age 18-60) \\
& $(1)$ & $(2)$ & $(3)$ & $(4)$ & $(5)$ & $(6)$ \\
\hline \hline Treatment group (yes=1, no=0) & $-0.183^{* * *}$ & $-0.202^{* * *}$ & $-0.407 * * *$ & $-0.370^{* * *}$ & $-0.226^{* * *}$ & $-0.281^{* * *}$ \\
& $(0.010)$ & $(0.011)$ & $(0.007)$ & $(0.007)$ & $(0.006)$ & $(0.006)$ \\
After treatment (2001=1, 1996=0) & $0.059^{* * *}$ & $0.052^{* * *}$ & $0.028^{* * *}$ & $0.022^{* * *}$ & $0.044^{* * *}$ & $0.041^{* * *}$ \\
& $(0.010)$ & $(0.010)$ & $(0.007)$ & $(0.007)$ & $(0.003)$ & $(0.003)$ \\
After treatment*Treatment group & $0.052^{* * *}$ & $0.053^{* * *}$ & $0.083^{* * *}$ & $0.083^{* * *}$ & $0.067 * * *$ & $0.070^{* * *}$ \\
& $(0.014)$ & $(0.014)$ & $(0.010)$ & $(0.010)$ & $(0.009)$ & $(0.009)$ \\
Individual control variables & No & Yes & No & Yes & No & Yes \\
\hline $\mathrm{N}$ & 19,986 & 19,986 & 25,900 & 25,107 & 108,746 & 101,485 \\
$\mathrm{R}^{2}$ & 0.03 & 0.08 & 0.18 & 0.21 & 0.02 & 0.10 \\
\hline
\end{tabular}

Notes: The table shows difference-in-differences estimates; robust standard errors in parentheses. The year 1996 constitutes the baseline year, while the year 2001 is the post-treatment year. As controls in Column 2 are included mother's age, mothers' highest school degree, nationality, a dummy for single mothers, and the age distance of the youngest children to their oldest siblings. In Columns 4 and 6 we included women's age, women's highest school degree, and nationality as control variables. $* * * 1 \%$ level of significance, $* * 5 \%$ level of significance, $* 10 \%$ level of significance. Data: Micro Census. 
Table 7: Placebo difference-in-differences estimations in pre-treatment periods

\begin{tabular}{|c|c|c|c|c|c|c|}
\hline \multirow{3}{*}{ Control group: Women with... } & \multicolumn{6}{|c|}{ EMPLOYED (yes=1, no=0) } \\
\hline & \multicolumn{2}{|c|}{ 10-11-year-old kids } & \multicolumn{2}{|c|}{ No kids (age 29-36) } & \multicolumn{2}{|c|}{ No kids (age 18-60) } \\
\hline & $(1)$ & $(2)$ & (3) & (4) & $(5)$ & $(6)$ \\
\hline \multirow[t]{2}{*}{ Treatment group (yes $=1$, no $=0$ ) } & $-0.157 * * *$ & $-0.294 * * *$ & $-0.413^{* * *}$ & $-0.414 * * *$ & $-0.228 * * *$ & $-0.317 * * *$ \\
\hline & $(0.010)$ & $(0.011)$ & $(0.006)$ & $(0.008)$ & $(0.007)$ & $(0.007)$ \\
\hline \multirow[t]{2}{*}{ After treatment $(1996=1,1991=0)$} & $0.038 * * *$ & $0.039 * * *$ & 0.005 & 0.005 & $0.009^{* * *}$ & $0.012^{* * *}$ \\
\hline & $(0.011)$ & $(0.011)$ & $(0.008)$ & $(0.008)$ & $(0.003)$ & $(0.003)$ \\
\hline \multirow[t]{2}{*}{ After treatment*Treatment group } & $-0.026^{*}$ & $-0.026 *$ & 0.006 & 0.007 & 0.002 & 0.004 \\
\hline & $(0.014)$ & $(0.014)$ & $(0.011)$ & $(0.011)$ & $(0.009)$ & $(0.009)$ \\
\hline Individual control variables & No & Yes & No & Yes & No & Yes \\
\hline $\mathrm{N}$ & 19,303 & 19,303 & 23,198 & 23,198 & 102,427 & 102,427 \\
\hline $\mathrm{R}^{2}$ & 0.03 & 0.03 & 0.19 & 0.19 & 0.02 & 0.09 \\
\hline
\end{tabular}

Notes: The table shows placebo difference-in-differences estimates in pre-treatment periods; robust standard errors in parentheses. The year 1991 constitutes the baseline year, while the year 1996 is the placebo post-treatment year. As controls in Columns 2, 4, and 6,) we included the woman's age. We did not include further covariates due to questionable comparability of the respective survey questions over time. $* * * 1 \%$ level of significance, $* * 5 \%$ level of significance, $* 10 \%$ level of significance. Data: Micro Census. 